\title{
Influence of Last Glacial Maximum boundary conditions on the global water isotope distribution in an atmospheric general circulation model
}

\author{
T. Tharammal ${ }^{1}$, A. Paul ${ }^{1,2}$, U. Merkel ${ }^{1,2}$, and D. Noone ${ }^{3}$ \\ ${ }^{1}$ Department of Geosciences, University of Bremen, Bremen, Germany \\ ${ }^{2}$ MARUM - Center for Marine Environmental Sciences, University of Bremen, Bremen, Germany \\ ${ }^{3}$ Department of Atmospheric and Oceanic Sciences and Cooperative Institute for Research in Environmental Sciences, \\ University of Colorado, Boulder, USA \\ Correspondence to: T. Tharammal (ttharammal@marum.de)
}

Received: 24 March 2012 - Published in Clim. Past Discuss.: 18 April 2012

Revised: 15 February 2013 - Accepted: 20 February 2013 - Published: 20 March 2013

\begin{abstract}
To understand the validity of $\delta^{18} \mathrm{O}$ proxy records as indicators of past temperature change, a series of experiments was conducted using an atmospheric general circulation model fitted with water isotope tracers (Community Atmosphere Model version 3.0, IsoCAM). A pre-industrial simulation was performed as the control experiment, as well as a simulation with all the boundary conditions set to Last Glacial Maximum (LGM) values. Results from the preindustrial and LGM simulations were compared to experiments in which the influence of individual boundary conditions (greenhouse gases, ice sheet albedo and topography, sea surface temperature (SST), and orbital parameters) were changed each at a time to assess their individual impact. The experiments were designed in order to analyze the spatial variations of the oxygen isotopic composition of precipitation $\left(\delta^{18} \mathrm{O}_{\text {precip }}\right)$ in response to individual climate factors. The change in topography (due to the change in land ice cover) played a significant role in reducing the surface temperature and $\delta^{18} \mathrm{O}_{\text {precip }}$ over North America. Exposed shelf areas and the ice sheet albedo reduced the Northern Hemisphere surface temperature and $\delta^{18} \mathrm{O}_{\text {precip }}$ further. A global mean cooling of $4.1^{\circ} \mathrm{C}$ was simulated with combined LGM boundary conditions compared to the control simulation, which was in agreement with previous experiments using the fully coupled Community Climate System Model (CCSM3). Large reductions in $\delta^{18} \mathrm{O}_{\text {precip }}$ over the LGM ice sheets were strongly linked to the temperature decrease over them. The SST and ice sheet topography changes were responsible for
\end{abstract}

most of the changes in the climate and hence the $\delta^{18} \mathrm{O}_{\text {precip }}$ distribution among the simulations.

\section{Introduction}

The Last Glacial Maximum (LGM, about $19000-23000 \mathrm{yr}$ before present) marks the peak of the last glacial period between about 110000 and $10000 \mathrm{yr}$ before present. A strong cooling in both hemispheres is recorded in proxy records from Greenland (Dahl-Jensen et al., 1998) and Antarctica (Stenni et al., 2004; EPICA community members, 2004). During the LGM, a large portion of North America and northern Eurasia was covered by ice sheets, hence the sea level was reduced by about $120 \mathrm{~m}$ (Fairbanks, 1989; Lambeck and Chappell, 2001). The newly exposed land areas and differences in vegetation and soil type impacted the surface albedo. The Laurentide ice sheet covering most of Canada and a large portion of the northern United States had a firstorder impact on the large-scale atmospheric circulation in the Northern Hemisphere via topographic and thermal forcing as demonstrated in global circulation models (e.g. Hansen et al., 1984; Manabe and Broccoli, 1985). A reduced atmospheric concentration of $\mathrm{CO}_{2}$ (185 ppmv, Petit et al., 1999) compared to the pre-industrial (PI, approximately $1800 \mathrm{AD}$ ) value of $280 \mathrm{ppmv}$ also influenced climate, as reduced greenhouse gas (GHG) levels have a direct effect on radiative forcing (Shin et al., 2002). 
Sensitivity studies using slab ocean models (e.g. Manabe and Broccoli, 1985) find that the reduction in GHG is accountable for the global cooling during the LGM, whereas the ice sheets induce a regional cooling in the Northern Hemisphere. Hewitt and Mitchell (1997) and Kim (2004), using coupled atmosphere-ocean general circulation models, similarly conclude that the ice sheet topography is a dominant factor in reducing the surface temperature in the Northern Hemisphere. A recent sensitivity study by Pausata et al. (2011a) finds that the ice sheet topography also plays a key role in altering the circulation pattern over the North Atlantic Ocean. These studies demonstrate the importance of studying the relative role of individual Last Glacial Maximum boundary conditions.

Changes in atmospheric temperature and circulation are closely reflected in the relative abundance of the isotopes of the water molecule $\mathrm{H}_{2}{ }^{16} \mathrm{O}, \mathrm{H}_{2}{ }^{18} \mathrm{O}$ and $\mathrm{HDO}$, which is why these isotopes are useful indicators of current and past climate changes (Dansgaard, 1964; Jouzel, 2003; Noone and Sturm, 2009). A temperature-dependent isotopic fractionation occurs during any phase transition because of the differences in their saturation vapor pressures. This causes the ratios of the heavier to lighter isotopes in the different reservoirs of the hydrological cycle to vary depending on the atmospheric conditions (Gat, 1996). In our study, we focused on $\mathrm{H}_{2}{ }^{16} \mathrm{O}$ and $\mathrm{H}_{2}{ }^{18} \mathrm{O}$.

The ratios of the heavy to the light isotopes are denoted by so-called $\delta$ values, given as $\delta^{18} \mathrm{O}=\left(R_{\mathrm{SAMPLE}} / R_{\mathrm{VSMOW}}-\right.$ $1) \times 1000 \%$, where $R$ is the ratio of the abundance of the heavier oxygen isotope ${ }^{18} \mathrm{O}$ to the abundance of the lighter isotope ${ }^{16} \mathrm{O}$. Furthermore, $R_{\text {SAMPLE }}$ and $R_{\text {VSMOW }}=$ $2.0052 \times 10^{-3} \%$ are the isotopic concentrations of the sample and of VSMOW (Vienna Standard Mean Ocean Water), respectively. In the tropics, $\delta^{18} \mathrm{O}$ in precipitation $\left(\delta^{18} \mathrm{O}_{\text {precip }}\right)$ is closely related to the precipitation amount ("amount effect", Dansgaard, 1964). Thus, highly depleted stable isotope concentrations are observed during time periods of intense precipitation (Rozanski et al., 1993). At high latitudes, $\delta^{18} \mathrm{O}_{\text {precip }}$ is strongly correlated with the local surface temperature ("temperature effect", Dansgaard, 1964; Rozanski et al., 1993), and for temperatures below $14{ }^{\circ} \mathrm{C}$, the annual mean $\delta^{18} \mathrm{O}_{\text {precip }}$ is closely related to the annual mean surface temperature $T$ as $\delta^{18} \mathrm{O}=0.62 \%{ }^{\circ} \mathrm{C}^{-1} T-15.25 \%$ (Dansgaard et al., 1973; Johnsen et al., 1989). Models have been used to determine whether this present-day temperature$\delta^{18} \mathrm{O}_{\text {precip }}$ relationship could be extended to climates that differ starkly from the present (e.g. Lee et al., 2008).

Stable water isotopes have been included in the hydrological cycle of various global atmospheric models, namely, GISS (Jouzel et al., 1987), ECHAM (Hoffmann et al., 1998), MUGCM (Noone and Simmonds, 2002), CAM2.0 (Lee et al., 2007), LMDZ (Bony et al., 2008), CAM3.0 (Noone and Sturm, 2009) and the atmosphere-ocean coupled model HadCM3 (Tindall et al., 2009). These models have been successfully used for simulating the present and paleoclimatic distributions of the stable isotopes in the global hydrological cycle.

Charles et al. (1994) found that changes in moisture transport and source regions for Greenland at the LGM may have produced an isotopic response independently of temperature changes. A similar result has also been found for shorter (millennial-scale) climate variations (Liu et al., 2012). Masson-Delmotte et al. (2006) showed that a major part of Greenland and Antarctic coolings of the general circulation model (GCM) simulations is caused by the prescribed local elevation increase due to ice sheets at the LGM. Werner et al. (2000) found an increased seasonality in the annual cycle of precipitation over Greenland during the LGM, but not over Antarctica. Conventionally, the spatial slope over a region (the relationship between $\delta^{18} \mathrm{O}_{\text {precip }}$ and temperature over a region) was assumed to hold through different climates, irrespective of time, and the temporal slope (relationship of $\delta^{18} \mathrm{O}_{\text {precip }}$ with surface temperature at a single geographical location through different climates over time) was considered to be similar to the spatial slope (Jouzel, 2003). Modeling studies (for example, Lee et al., 2008) find that the apparent temporal slope over eastern Antarctica is half of the observed spatial slope for the LGM and that the value of the temporal slope is related to the temperature decrease over the Southern Ocean. These studies point to the importance of understanding the influence of the various forcing factors on the isotope distribution.

In our study, we aim to understand the change in $\delta^{18} \mathrm{O}_{\text {precip }}$ during the LGM and associate the changes to the influence of the different boundary condition constraints. Following Broccoli and Manabe (1987b), we employed a similar method using an atmospheric general circulation model to test the effect of the individual boundary conditions on the Last Glacial Maximum climate in terms of surface temperature, precipitation and $\delta^{18} \mathrm{O}_{\text {precip }}$.

\section{The model and experiments}

\subsection{The model}

We used the NCAR Community Atmosphere Model CAM3.0 (Collins et al., 2006) with a water isotope scheme included, hereafter referred to as IsoCAM. The isotopic version of CAM is based on the earlier isotopic scheme of Noone and Simmonds (2002), but includes a more sophisticated treatment of surface exchange and cloud processes to make use of the multiple water phases predicted by CAM (Noone, 2003, 2006; Noone and Sturm, 2009; Sturm et al., 2010). The spatial resolution employed in our experiments corresponds to a spectral truncation of T31 and 26 hybrid levels in the vertical. The related Gaussian grid has a spatial resolution of approximately $3.75^{\circ}$ ( 48 grid points in latitude and 96 grid points in longitude). Each atmospheric grid box in CAM3.0 contains a specific fraction of land, ice, or ocean. 
The ability of CAM3.0 to efficiently simulate the global hydrological cycle is detailed in Hack et al. (2006).

CAM is coupled to the Community Land Model, CLM (Bonan et al., 2002), which uses the same grid as the atmospheric model. CLM includes different forms of land surface types within each grid cell, namely lakes, glaciers, wetlands and up to 16 land plant functional types (PFTs) that can include a bare soil (Dickinson et al., 2006). For the calculation of isotope ratios over land, a simple bucket model (Manabe, 1969 ) is used, which does not differentiate between evaporation and river runoff or different soil types (Deardorff, 1977; Noone and Simmonds, 2002). The isotope ratios over land do not take into account the fractionation during evapotranspiration or the effect of different vegetation types.

A thermodynamic sea-ice model (CSIM) represents the sea-ice component of the model. CSIM computes the surface fluxes when used with prescribed sea surface temperature (SST). It further predicts snow depth, brine pockets, internal shortwave radiative transfer, surface albedo, ice-atmosphere drag and surface exchange fluxes without the use of a flux coupler (Collins et al., 2006).

The stable isotope ratios of water in the hydrological cycle of IsoCAM are transported through the atmosphere and the ground by the same processes (advection, moist convection, evapotranspiration, etc.) used to transport normal water (Noone and Sturm, 2009). The isotopes of hydrogen are also included in the model, but were not analyzed in the present study. The isotopic fractionation occurs with every phase change of the water species in the model hydrology. IsoCAM employs a semi-Lagrangian formulation for the water vapor and tracer transport (Williamson and Rasch, 1993; Williamson and Olson, 1994). This formulation uses a shape-preserving interpolation method (Williamson and Rasch, 1989), which avoids the generation of spurious minima or maxima through supersaturation by the transport of water vapor (Williamson and Rasch, 1993). The scheme has been found to be sufficiently accurate for conserving isotopic ratios during advection to low-temperature environments (Noone and Simmonds, 2002; Noone and Sturm, 2009); however, it does not guarantee mass conservation (Staniforth and Côté, 1991; Rasch and Williamson, 1990; Williamson and Rasch, 1993; Williamson and Olson, 1994). A "mass fixer" that repeatedly restores global mass is used in CAM3.0 to account for this imbalance (Collins et al., 2004). Studies with the MUGCM (Noone and Simmonds, 2002) find that the application of such a mass fixer leads to fictitious changes in the isotope distribution, as the mass restoration is not local and the mass is not balanced where the spurious sinks/sources have removed/added the mass, which affects especially the polar regions. Since IsoCAM gives a better tracer-tracer correlation without the application of an a posteriori mass fixer (not shown), our simulations were carried out without mass fixing.

\subsection{Experiments and boundary conditions}

A simulation with all the boundary conditions set to LGM values was carried out following the PMIP2 (Paleoclimate Modelling Intercomparison Project Phase II) protocol (LGM-combined hereafter). In addition, a series of experiments was carried out by changing the individual boundary conditions (greenhouse gases, ice sheet albedo and topography, SST along with sea-ice concentration, orbital parameters) each at a time to LGM values. A pre-industrial (PI, approximately $1800 \mathrm{AD}$ ) simulation with boundary conditions also according to the PMIP2 protocol (Braconnot et al., 2007) served as the control run. The extent and the height of the ice sheets at the LGM were taken from the ICE-5G ice sheet topography (Peltier, 2004). The SST datasets for the pre-industrial and LGM periods were derived from previous fully coupled CCSM3 simulations (Merkel et al., 2010). For the SST and LGM-combined simulations, the SST dataset for the LGM was used; for all other simulations, the preindustrial SST dataset was chosen. In comparison to a multiproxy reconstruction of the LGM SST from the MARGO project (MARGO, 2009), the model's LGM SST anomaly with respect to PI (Fig. S1 in the Supplement) shows a tropical cooling largely consistent with the MARGO estimate. However, the proxy data suggest a stronger cooling near the western coasts of Africa and South America than the model. Otto-Bliesner et al. (2009) attribute this reduced cooling in the simulations to model deficiencies that produce biases in tropical upwelling and the thermocline structure, and to insufficient model resolution. Other PMIP2 models show similar differences from the proxy data (Braconnot et al., 2012). The PI and LGM SST data used for our simulations were very similar to the results of higher resolution CCSM3 experiments (Otto-Bliesner et al., 2006a).

For all our experiments, the sea surface oxygen and hydrogen isotope ratios were set to the global mean surface ocean values of $0.5 \%$ and $4 \%$, respectively (cf. Craig and Gordon, 1965).

The boundary conditions for each experiment are listed in Tables 1 and 2. The orbital parameters for the pre-industrial control, GHG, albedo and topography simulations were prescribed to the reference values of $1950 \mathrm{AD}$, while the orbital parameters for the orbital-only and for the LGM-combined simulation were set to the $21 \mathrm{ka}$ BP values (Berger, 1978). In the GHG experiment, only the atmospheric greenhouse gas concentrations were reduced to the LGM concentrations to show the direct influence of changes in atmospheric heating due to infrared absorption, rather than the fully integrated climate response to lower GHG concentrations during the LGM, which is better captured by the stronger forcing provided by prescribing the LGM SSTs. The albedo experiment was conducted by replacing the land ice cover of the PI simulation with LGM values, thereby only changing the surface albedo to that of the LGM. The topography experiment was conducted by taking into account the change in ice sheet 
Table 1. Summary of experiments and boundary conditions.

\begin{tabular}{llclll}
\hline Experiment & SST & Orbital year & Topography & GHG & $\begin{array}{l}\text { Ice sheet } \\
\text { albedo }\end{array}$ \\
\hline PI & PI & 1950 & PI $^{1}$ & PI & PI $^{2}$ \\
GHG $_{(\text {LGM })}$ & PI & 1950 & PI & LGM & PI \\
Albedo $_{(\text {LGM })}$ & PI & 1950 & PI & PI & LGM \\
Topography $_{(\text {LGM })}$ & PI & 1950 & LGM & PI & PI \\
SST $_{(\text {LGM })}$ & LGM & 1950 & PI & PI & PI \\
Orbital $_{(\text {LGM })}$ & PI & $21 \mathrm{ka}$ & PI & PI & PI \\
LGM-combined & LGM & $21 \mathrm{ka}$ & LGM & LGM & LGM \\
\hline
\end{tabular}

${ }^{1}$ Present day values are used for the topography and coast lines in the PI (control) simulation following the PMIP2 protocol. ${ }^{2}$ Present day values are used for the ice sheets in the PI (control) simulation following the PMIP2 protocol.

Table 2. Atmospheric greenhouse gas concentrations for the PI and LGM time periods.

\begin{tabular}{lrr}
\hline $\begin{array}{l}\text { Greenhouse } \\
\text { gases }\end{array}$ & $\begin{array}{r}\text { Pre- } \\
\text { industrial }\end{array}$ & LGM \\
\hline $\mathrm{CO}_{2}$ (ppmv) & 280 & 185 \\
$\mathrm{CH}_{4}$ (ppbv) & 760 & 350 \\
$\mathrm{~N}_{2} \mathrm{O}$ (ppbv) & 270 & 200 \\
\hline
\end{tabular}

topography and the lowering of sea level during the LGM by $120 \mathrm{~m}$ (Fairbanks, 1989). All simulations were integrated for 35 model years, and the last $10 \mathrm{yr}$ of each simulation were used for analysis.

The coupled CCSM3.0 model has been shown to successfully reproduce the observed distributions of surface temperature and total precipitation, as described in Otto-Bliesner et al. (2006b) and Hack et al. (2006). Here the uncoupled CAM3.0 model is forced with a prescribed SST, and the analysis focuses on the changes to the $\delta^{18} \mathrm{O}$ of precipitation that are associated with this SST forcing and other boundary conditions. The annual and seasonal distributions of $\delta^{18} \mathrm{O}_{\text {precip }}$ for the PI control climate are shown in Fig. 1. The IsoCAM model captures well the main features of the annual mean $\delta^{18} \mathrm{O}_{\text {precip }}$ when compared to the Global Network of Isotopes in Precipitation (GNIP; IAEA/WMO, 2006) database (not shown). The temporal $\delta^{18} \mathrm{O}_{\text {precip-surface temperature (TS) }}$ slope between the control run and the LGM-combined simulation was calculated as a linear fit for Antarctica and Greenland as $S_{\text {temporal }}=\left[\delta^{18} \mathrm{O}_{\text {precip }}(\mathrm{LGM})-\delta^{18} \mathrm{O}_{\text {precip }}(\mathrm{PI})\right] /[\mathrm{TS}$ (LGM) - TS(PI)]. This relationship is a critical metric for interpreting model results because it is most pertinent for estimating past temperature from ice core records. The insight offered by the IsoCAM is in association with the simulated changes in $\delta^{18} \mathrm{O}_{\text {precip }}$ that correspond to the changes in TS, which in turn result from a systematic variation of the boundary conditions.

\section{Geographical annual mean responses in surface temperature and precipitation}

Because the experimental design makes use of the atmospheric component forced by conditions that result from a coupled model, it is prudent to confirm the performance of the uncoupled simulation. The impact of the glacial boundary conditions on the surface temperature and precipitation in defined geographical regions is summarized in Tables 3 and 4 , respectively. The global annual mean cooling in the surface temperature was $4.1^{\circ} \mathrm{C}$ in our LGM-combined experiment with respect to the PI experiment, while the reduction of global annual mean precipitation was $0.22 \mathrm{~mm} \mathrm{day}^{-1}$, in good agreement with previous coupled simulations using CCSM3 (Otto-Bliesner et al., 2006a). The SST experiment brought about a global mean cooling of $2.79{ }^{\circ} \mathrm{C}$. The direct influence of albedo and $\mathrm{GHG}$ changes was a cooling of $0.18^{\circ} \mathrm{C}$ and $0.14^{\circ} \mathrm{C}$ in these experiments, respectively, which was comparatively small, and much smaller than the response that results from them when coupled with ocean surface temperature. The fixed SST suppressed the oceanatmosphere feedback and so only the land temperature was free to interact with the $\mathrm{CO}_{2}$ change. The change in topography caused a mean cooling of $0.59{ }^{\circ} \mathrm{C}$ in the Northern Hemisphere $(\mathrm{NH})$, while in the Southern Hemisphere $(\mathrm{SH})$ the magnitude of the induced cooling was only $0.27^{\circ} \mathrm{C}$. The global mean cooling in the orbital experiment was the weakest among all the simulations. The precipitation in the tropics was reduced in all the experiments except for the GHG simulation and showed the strongest response in the SST experiment. The global annual mean energy budgets for our simulations are summarized in Table 5. The annual global energy imbalance for the control run at the top of the model (TOM) and the surface was $-2.39 \mathrm{~W} \mathrm{~m}^{-2}$ and $+5.12 \mathrm{~W} \mathrm{~m}^{-2}$ (a positive sign means that the system is gaining heat), respectively. The TOM and surface residual energy imbalances for the LGM-GHG and LGM-SST experiments were larger than for the PI experiment. The model conserves energy within $(7.5 \pm 0.2) \mathrm{W} \mathrm{m}^{-2}$ for all experiments. Since the model is 

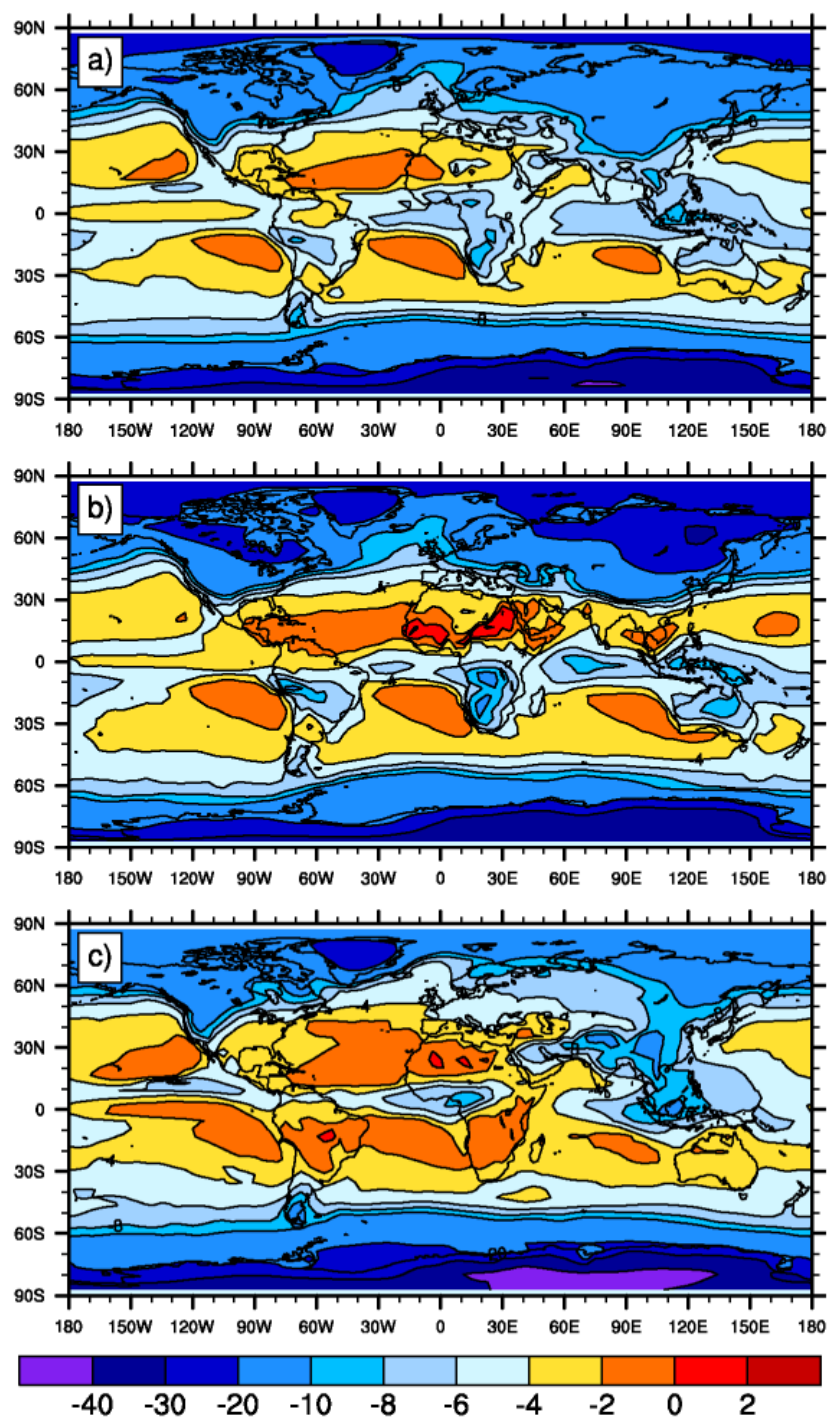

Fig. 1. Global distribution of $\delta^{18} \mathrm{O}_{\text {precip }}(\%)$ for the control run: (a) annual mean, (b) December-January-February (DJF) season, and (c) June-July-August (JJA) season.

forced with a prescribed SST dataset, the model need not be in energy balance. The surface latent heat flux was higher in the GHG experiment in association with lower global relative humidity due to changes in the atmospheric longwave heating profile, while it was reduced in other experiments.

\section{Zonal mean response of $\delta^{18} \mathrm{O}$ in precipitation}

The orbital, GHG, and albedo experiments produced lower $\delta^{18} \mathrm{O}_{\text {precip }}$ values in the northern high latitudes (Fig. 2). The topography changes also produced lower $\delta^{18} \mathrm{O}_{\text {precip }}$ values by 1 to $2 \%$ in the northern high latitudes, where the zonal mean surface temperature (not shown) was reduced by 2 to $3{ }^{\circ} \mathrm{C}$; and by 2 to $3 \%$ in the southern high latitudes, which was associated both with the significant altitude change over

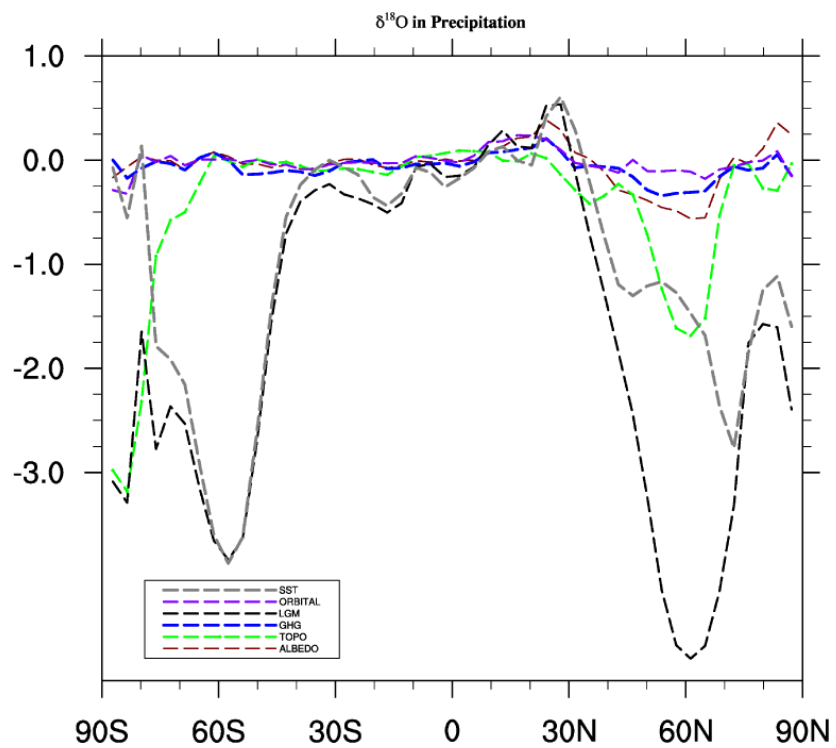

Fig. 2. The difference of zonal mean $\delta^{18} \mathrm{O}_{\text {precip }}(\% \circ)$ of each experiment from the control run.

the Antarctic ice sheet and changes to the atmospheric circulation over the Southern Ocean. The LGM-combined experiment yielded a strong response in the Southern Hemisphere mid-latitudes and in the south polar regions with a depletion by 2 to $4 \%$. The SST experiment and the LGM-combined experiment showed similar higher $\delta^{18} \mathrm{O}_{\text {precip }}$ values in the tropics and equatorial regions where the precipitation was reduced by $5-10 \%$ (not shown). In the higher latitudes, however, the effect of the ice sheet albedo and topography in the LGM-combined experiment led to lower $\delta^{18} \mathrm{O}_{\text {precip values as }}$ compared to the SST simulation.

\section{Annual mean spatial response to the different forcings}

\subsection{Global responses of $\delta^{18} \mathrm{O}_{\text {precip }}$}

The annual mean spatial responses in surface temperature, $\delta^{18} \mathrm{O}_{\text {precip }}$ and precipitation are shown in Figs. 3, 4 and 5, respectively.

The temperature (Fig. 3a) and precipitation (Fig. 5a) responses to the direct GHG forcing were small and were only seen over land because the SST was prescribed. A reduced atmospheric $\mathrm{CO}_{2}$ concentration in a coupled simulation would have directly affected the amount of outgoing longwave radiation and reduced the net downward heat flux at the ocean surface, thereby cooling the ocean surface. Globally, the $\delta^{18} \mathrm{O}_{\text {precip }}$ response (Fig. 4a) was small, and regions of low temperature in the high latitudes were characterized by low $\delta^{18} \mathrm{O}_{\text {precip values. }}$

The effect of the albedo change was seen predominantly in the Northern Hemisphere as the increased albedo of the ice-covered grid cells (i.e. without topographic change due 
Table 3. Annual mean surface temperature (TS) in ${ }^{\circ} \mathrm{C}$ over the globe $\left(\mathrm{TS}_{\mathrm{global}}\right)$, land points alone $\left(\mathrm{TS}_{\text {land }}\right)$, Northern and Southern hemispheres $\left(\mathrm{TS}_{\mathrm{NH}}, \mathrm{TS}_{\mathrm{SH}}\right)$, and tropics $\left(\mathrm{TS}_{\text {tropics }} ; 20^{\circ} \mathrm{S}\right.$ to $\left.20^{\circ} \mathrm{N}\right)$ in the different experiments. The difference to the control experiment is given in the adjacent columns.

\begin{tabular}{|c|c|c|c|c|c|c|c|c|c|c|}
\hline \multirow{2}{*}{$\begin{array}{l}\text { Experiment } \\
\text { PI }\end{array}$} & \multicolumn{2}{|c|}{$\mathrm{TS}_{\text {global }}$} & \multicolumn{2}{|c|}{$\mathrm{TS}_{\text {land }}$} & \multicolumn{2}{|c|}{$\mathrm{TS}_{\mathrm{NH}}$} & \multicolumn{2}{|c|}{$\mathrm{TS}_{\mathrm{SH}}$} & \multicolumn{2}{|c|}{$\mathrm{TS}_{\text {tropics }}$} \\
\hline & \multicolumn{2}{|c|}{12.89} & \multicolumn{2}{|c|}{6.70} & \multicolumn{2}{|c|}{13.057} & \multicolumn{2}{|c|}{13.01} & \multicolumn{2}{|c|}{25.66} \\
\hline $\mathrm{GHG}_{(\mathrm{LGM})}$ & 12.75 & -0.14 & 6.28 & -0.42 & 12.82 & -0.24 & 12.96 & -0.05 & 25.63 & -0.03 \\
\hline Albedo $_{(\mathrm{LGM})}$ & 12.71 & -0.18 & 6.08 & -0.62 & 12.69 & -0.37 & 13.00 & -0.01 & 25.66 & 0.00 \\
\hline Topography $_{(\mathrm{LGM})}$ & 12.45 & -0.44 & 5.32 & -1.38 & 12.47 & -0.59 & 12.73 & -0.27 & 25.53 & -0.13 \\
\hline $\operatorname{Orbital}_{(\mathrm{LGM})}$ & 12.86 & -0.02 & 6.31 & -0.38 & 13.00 & -0.05 & 13.01 & 0.0 & 25.67 & 0.01 \\
\hline $\mathrm{SST}_{(\mathrm{LGM})}$ & 10.10 & -2.79 & 2.93 & -3.76 & 10.27 & -2.78 & 9.92 & -3.08 & 24.00 & -1.65 \\
\hline LGM-combined & 8.79 & -4.1 & -0.52 & -7.22 & 8.35 & -4.71 & 9.58 & -3.42 & 23.84 & -1.83 \\
\hline
\end{tabular}

Table 4. As Table 3, but for precipitation in $\mathrm{mm} \mathrm{day}^{-1}$.

\begin{tabular}{|c|c|c|c|c|c|c|c|c|c|c|}
\hline \multirow{3}{*}{$\begin{array}{l}\text { Experiment } \\
\text { PI } \\
\text { GHG }_{(\mathrm{LGM})}\end{array}$} & \multirow{2}{*}{\multicolumn{2}{|c|}{$\begin{array}{c}\text { precip }_{\text {global }} \\
2.77\end{array}$}} & \multirow{2}{*}{\multicolumn{2}{|c|}{$\frac{\text { precip }_{\text {land }}}{2.10}$}} & \multirow{2}{*}{\multicolumn{2}{|c|}{$\begin{array}{c}\text { precip }_{\mathrm{NH}} \\
2.64\end{array}$}} & \multirow{2}{*}{\multicolumn{2}{|c|}{$\begin{array}{c}\text { precip }_{\mathrm{SH}} \\
2.90\end{array}$}} & \multirow{2}{*}{\multicolumn{2}{|c|}{$\begin{array}{c}\text { precip }_{\text {tropics }} \\
4.44\end{array}$}} \\
\hline & & & & & & & & & & \\
\hline & 2.80 & 0.03 & 2.05 & -0.04 & 2.67 & 0.03 & 2.94 & 0.03 & 4.49 & 0.04 \\
\hline Albedo $_{(\mathrm{LGM})}$ & 2.76 & -0.00 & 2.06 & -0.04 & 2.62 & -0.01 & 2.91 & 0.01 & 4.43 & -0.01 \\
\hline Topography $_{(\mathrm{LGM})}$ & 2.75 & -0.01 & 2.12 & 0.01 & 2.61 & -0.02 & 2.89 & -0.01 & 4.40 & -0.04 \\
\hline $\operatorname{Orbital}_{(\mathrm{LGM})}$ & 2.77 & 0.0 & 2.10 & 0.0 & 2.64 & 0.0 & 2.90 & 0.0 & 4.43 & -0.01 \\
\hline $\mathrm{SST}_{(\mathrm{LGM})}$ & 2.55 & -0.22 & 1.98 & -0.12 & 2.39 & -0.24 & 2.70 & -0.20 & 4.15 & -0.28 \\
\hline LGM-combined & 2.55 & -0.22 & 1.86 & -0.24 & 2.38 & -0.25 & 2.71 & -0.18 & 4.17 & -0.27 \\
\hline
\end{tabular}

to ice sheets) caused a reduction in surface temperature by 1 to $5^{\circ} \mathrm{C}$ (Fig. 3b). $\delta^{18} \mathrm{O}_{\text {precip }}$ followed the temperature pattern with lower $\delta^{18} \mathrm{O}_{\text {precip }}$ values of 1.5 to $2 \%$ with a spatial slope of $0.67 \% 0^{\circ} \mathrm{C}^{-1}$ (Fig. $4 \mathrm{~b}$ ) over North America, and parts of Eurasia where the precipitation was also reduced compared to PI values (Fig. 5b).

The ice sheet topography experiment resulted in a strong cooling (approximately $-15^{\circ} \mathrm{C}$, Fig. 3c) and reduction in precipitation (Fig. 5c) in the regions of elevated orography, because the elevation change was about $2 \mathrm{~km}$ over the North American and Eurasian ice sheets and temperature decreases with altitude at a lapse rate of approximately $6.5^{\circ} \mathrm{C} \mathrm{km}^{-1}$. $\delta^{18} \mathrm{O}_{\text {precip }}$ was depleted by 5 to $15 \%$ (Fig. $4 \mathrm{c}$ ), and the model predicted a spatial slope of $\delta^{18} \mathrm{O}_{\text {precip }}$ vs. temperature of $0.61 \%{ }^{\circ} \mathrm{C}^{-1}$ over the North American ice sheets. The effect of changes in the orbital parameters on the simulated climate and $\delta^{18} \mathrm{O}_{\text {precip }}$ was small (Fig. 4d). Surface temperature was lowered by around $1{ }^{\circ} \mathrm{C}$ over parts of North America and Europe (Fig. 3d). Similar to the very weak surface temperature response, only small changes were seen in the precipitation with an increase in the range of 0.1 to $1 \mathrm{~mm} \mathrm{day}^{-1}$ over parts of the globe (Fig. 5d).

In the SST experiment, the surface temperature over the northern high latitudes and polar regions was reduced by more than $12{ }^{\circ} \mathrm{C}$ (Fig. 3e), a direct effect in response to the reduced SST. $\delta^{18} \mathrm{O}_{\text {precip }}$ was more depleted over the high latitudes with the reduced temperature and more enriched over the monsoonal regions, where a reduction in annual precip- itation was simulated (Fig. 4e). In the LGM-combined simulation, the ice sheets caused strong anomalies in temperature (Fig. 3f), $\delta^{18} \mathrm{O}_{\text {precip }}$ (Fig. 4f) and also in precipitation (Fig. 5f) over the North American land mass and parts of the North Atlantic Ocean, because the atmosphere became drier, especially in high latitudes. A strong cooling in surface temperature and a similar pattern of reduction in $\delta^{18} \mathrm{O}_{\text {precip }}$ with a spatial slope of $0.52 \% 0^{\circ} \mathrm{C}^{-1}$ over the expanded ice sheets were simulated, because of the colder and drier climate over them. Over the northern African continent and over the Indian subcontinent, higher $\delta^{18} \mathrm{O}_{\text {precip }}$ values of 0.5 to $2 \%$ o were simulated. The positive and negative anomalies in precipitation simulated over the tropics were similar to the response modeled in the SST experiment, which points to a local response in precipitation to the changes in SST.

\subsection{Regional mean responses of $\delta^{18} \mathrm{O}_{\text {precip }}$}

The annual mean $\delta^{18} \mathrm{O}_{\text {precip }}$ and the difference from the control experiment for North America, Eurasia, Greenland, northern Africa, southern Africa, northern and southern South America and Antarctica in each experiment are given in Table 6 (geographical regions defined by appropriate latitude-longitude boundaries). Over northern Africa a strong increase in $\delta^{18} \mathrm{O}_{\text {precip }}$ values was simulated in all the experiments compared to the control experiment, with the maximum response in the LGM-combined experiment $(1.57 \%)$. 

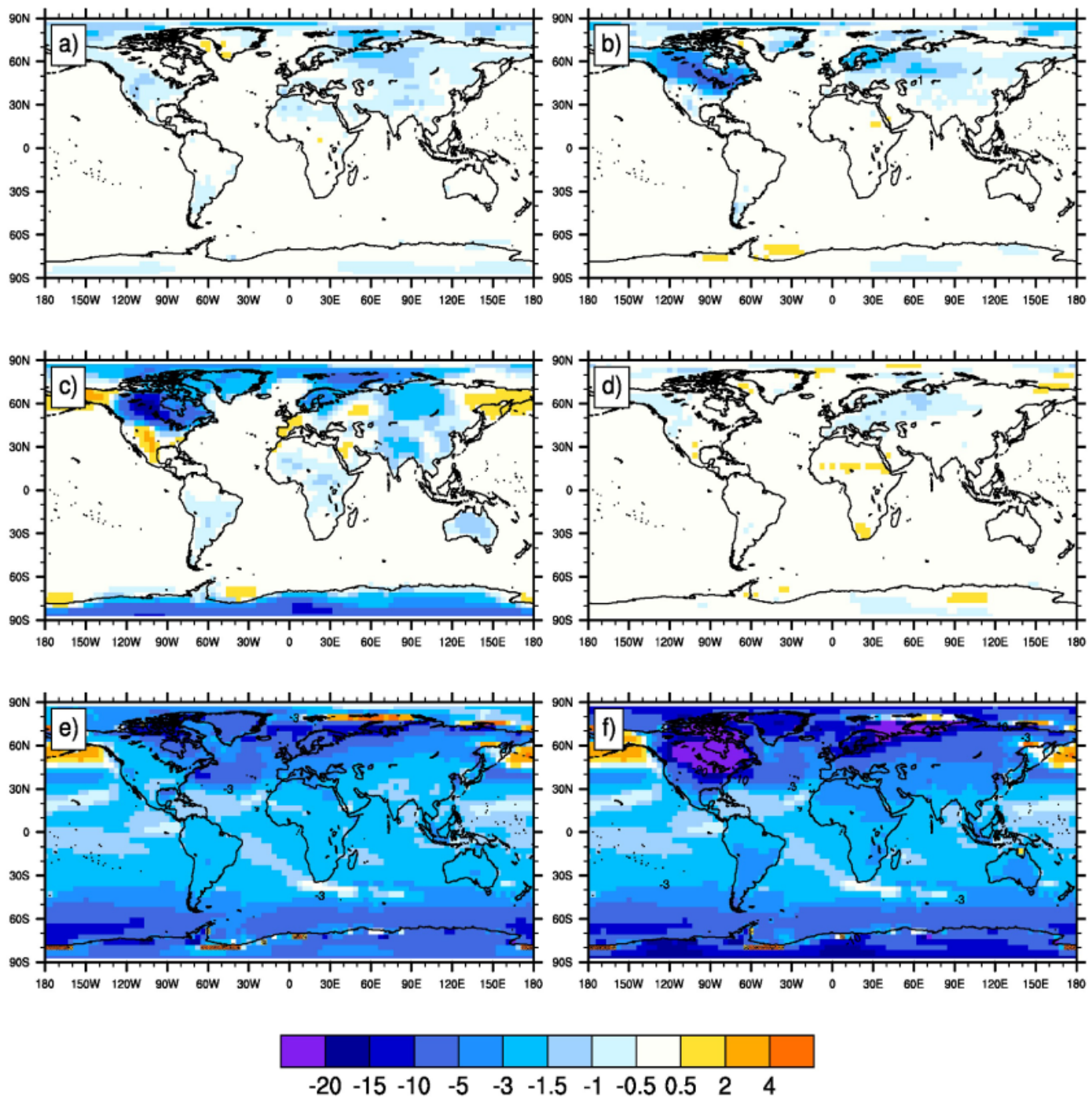

Fig. 3. Annual mean difference of surface temperature $\left({ }^{\circ} \mathrm{C}\right)$ of (a) GHG, (b) albedo, (c) topography, (d) orbital, (e) SST, and (f) LGMcombined experiments from the control run. Anomalies in the surface temperature at the margins of the Ross and Weddell seas in the SST and the LGM-combined experiments are stippled because the respective grid cells were erroneously defined as ocean.

Table 5. Global annual mean of energy terms in the model for the different experiments.

\begin{tabular}{lrrrrrrrr}
\hline Experiment & FSNT & FLNT & SHFLX & LHFLX & FSNS & FLNS & RESSURF & RESTOM \\
\hline PI & 231.28 & 233.4 & 22.36 & 73.57 & 157.35 & 56.03 & 5.39 & -2.12 \\
GHG $_{(\text {LGM }}$ & 230.76 & 235.54 & 22.72 & 74.55 & 156.91 & 56.89 & 2.75 & -4.88 \\
Albedo $_{(\text {LGM })}$ & 230.19 & 233.09 & 22.4 & 73.37 & 156.26 & 55.81 & 4.68 & -2.9 \\
Topography $_{(\mathrm{LGM})}$ & 230.6 & 232.73 & 22.33 & 72.87 & 156.79 & 55.99 & 5.6 & -2.13 \\
Orbital $_{(\mathrm{LGM})}$ & 231.17 & 233.28 & 22.35 & 73.5 & 157.22 & 55.91 & 5.46 & -2.11 \\
SST $_{(\mathrm{LGM})}$ & 228.82 & 228.1 & 23.78 & 67.58 & 156.35 & 56.98 & 8.01 & 0.72 \\
LGM-combined & 226.32 & 228.59 & 23.86 & 67.35 & 154.28 & 57.83 & 5.24 & -2.27 \\
\hline
\end{tabular}

All energy fluxes are given in units of $\mathrm{W} \mathrm{m}^{-2}$. FSNT: net solar flux at top of model (TOM), FLNT: outgoing longwave radiation at top of model, SHFLX: surface sensible heat flux, LHFLX: surface latent heat flux, FSNS: net solar flux at surface, FLNS: net longwave flux at surface, RESSURF: residual energy flux at the surface, and RESTOM: residual energy flux at the top of the model. 

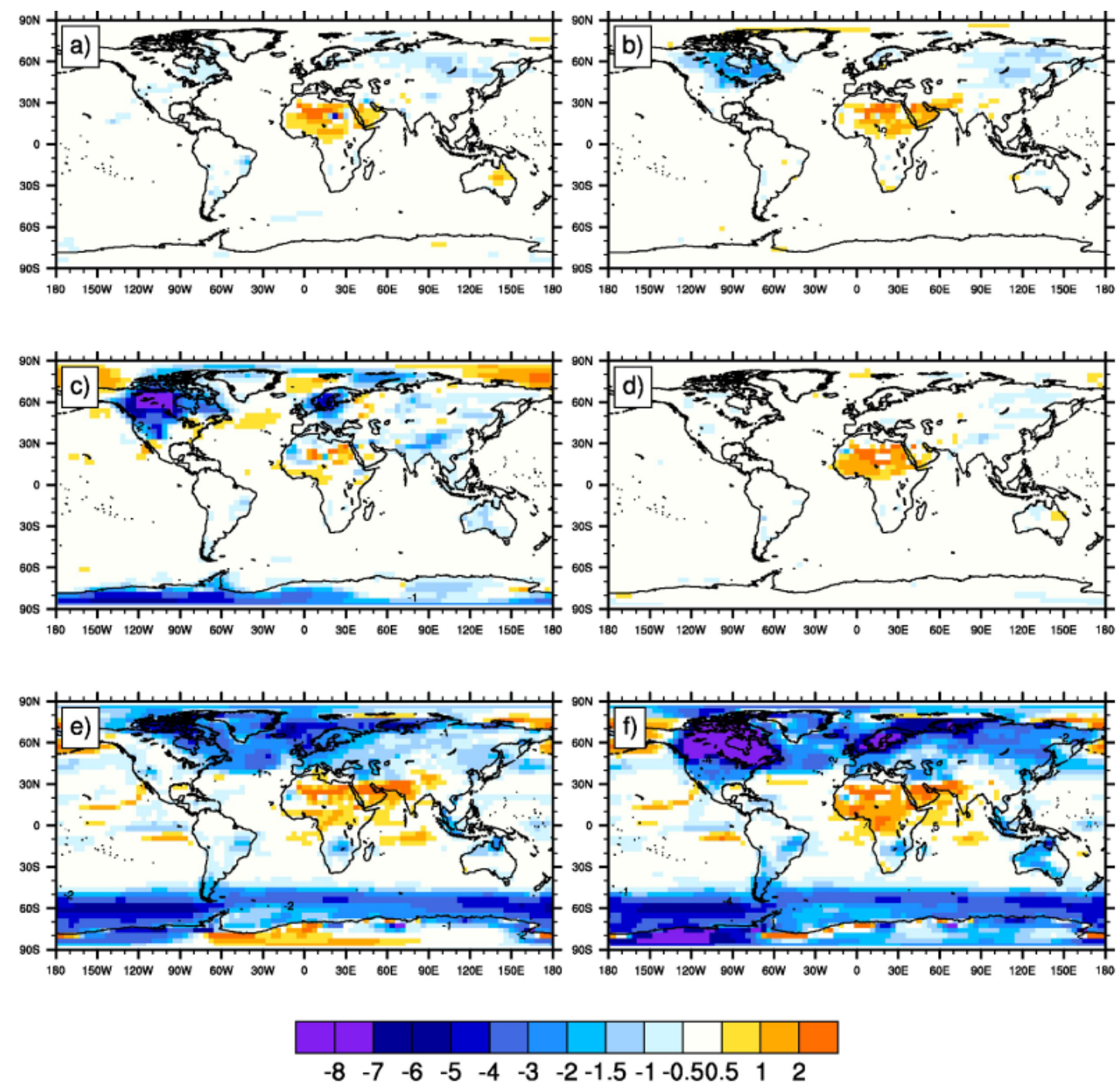

Fig. 4. Annual mean difference of $\delta^{18} \mathrm{O}_{\text {precip }}(\%$ ) of (a) GHG, (b) albedo, (c) topography, (d) orbital, (e) SST, and (f) LGM-combined experiments from the control run.

In southern Africa, the depletion was most pronounced in the SST and LGM-combined experiments, and the results showed the dependence of $\delta^{18} \mathrm{O}_{\text {precip }}$ on the SST change (a lower SST led to lower isotope values). Over Greenland, the mean value of $\delta^{18} \mathrm{O}_{\text {precip }}$ was $-22.3 \%$ in the LGMcombined experiment, and the SST experiment produced the largest signal among all experiments with a depletion by $2.6 \%$. The geographical region covered by the Eurasian ice sheet was more depleted by $5.9 \%$ in the LGM-combined experiment, whereas the topography and SST simulations produced a depletion by 2.1 and $2.7 \%$, respectively. Over the Laurentide ice sheet, the $\delta^{18} \mathrm{O}_{\text {precip }}$ was lower by $10.3 \%$ in the LGM-combined simulation and the topography change produced a decrease of $3.3 \%$. Over Antarctica, an area- averaged mean depletion of $2.2 \%$ in the LGM-combined simulation was obtained, whereas the topography and the SST experiments produced $\delta^{18} \mathrm{O}_{\text {precip }}$ values lower by about $1.2 \%$ each.

\subsection{The spatial relationship of $\delta^{18} \mathrm{O}_{\text {precip }}$ to surface tem- perature and precipitation}

In order to understand the relationship between annual mean $\delta^{18} \mathrm{O}_{\text {precip }}$ and surface temperature under different climate states, a simple linear regression analysis was used to calculate the spatial slopes over Greenland and Antarctica (Fig. 6a-d). Modeled annual mean values of surface temperature and $\delta^{18} \mathrm{O}_{\text {precip }}$ for all model grid boxes in inner Greenland and Antarctica were used for the calculation. 

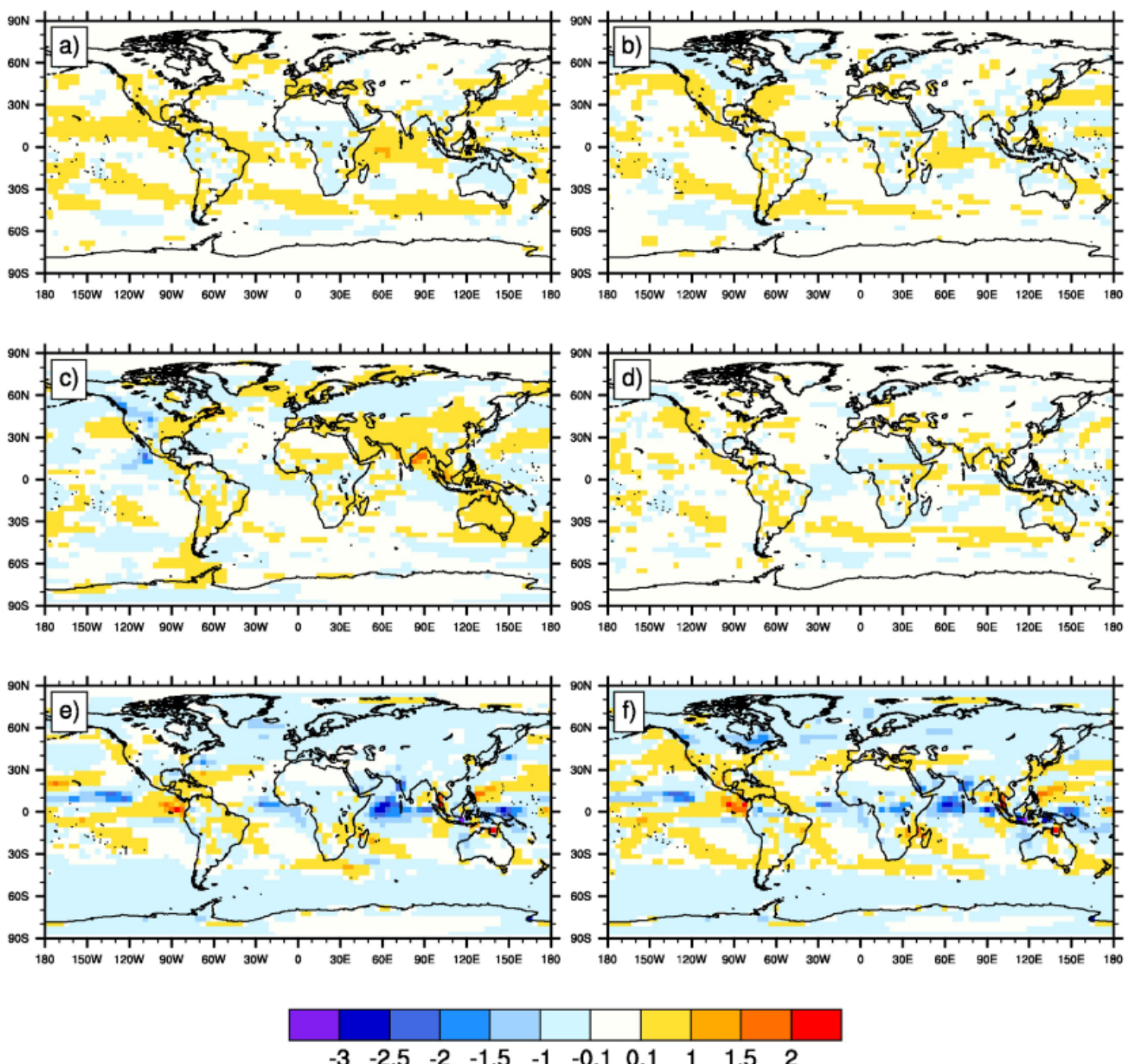

Fig. 5. Annual mean difference of total precipitation $\left(\mathrm{mmday}^{-1}\right.$ ) of (a) GHG, (b) albedo, (c) topography, (d) orbital, (e) SST, and (f) LGM-combined experiments from the control run.

Table 6. Annual mean $\delta^{18} \mathrm{O}_{\text {precip }}$ in $\%$ as area averages for selected geographical regions (given in brackets, also a land mask dataset for LGM was used to select the regions in specific) in the different experiments. The difference from the control experiment is given in brackets.

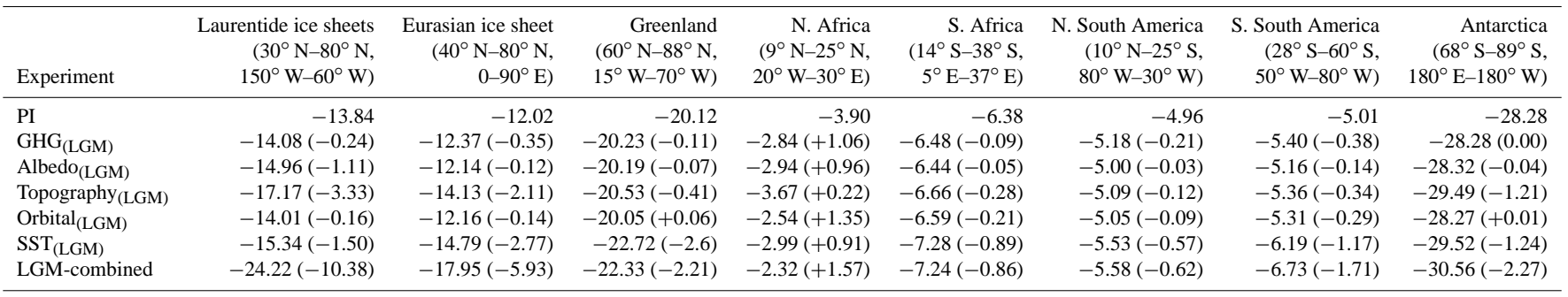



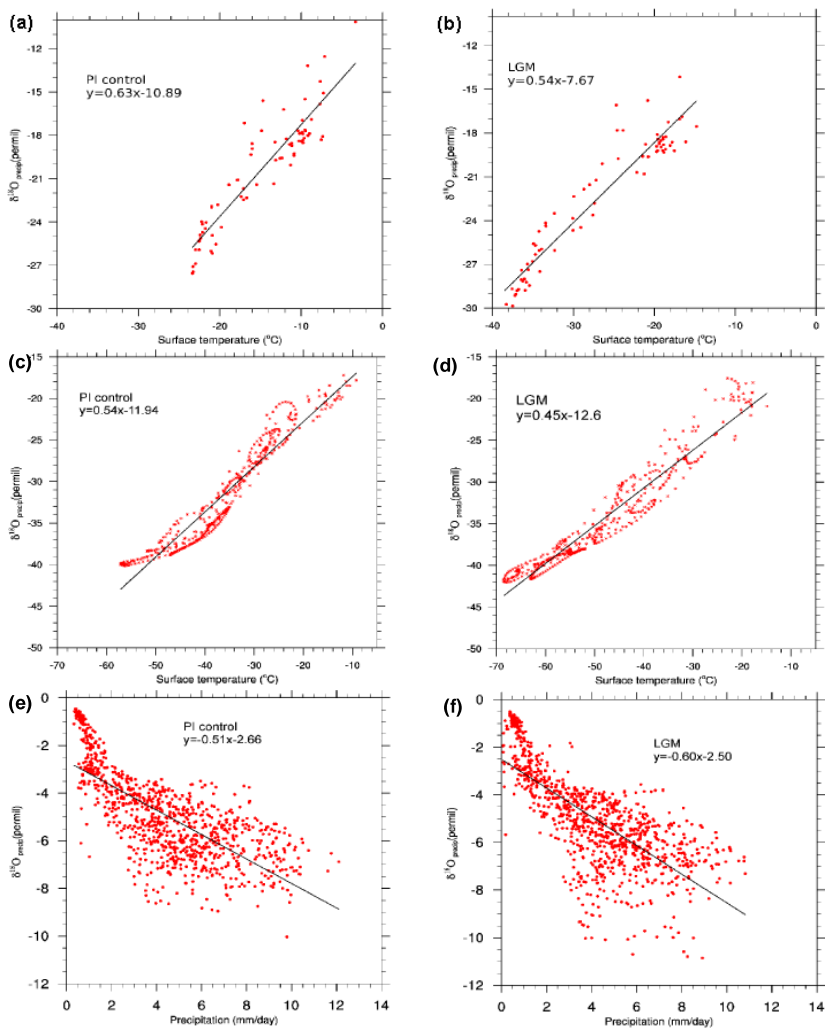

Fig. 6. The relationship between $\delta^{18} \mathrm{O}_{\text {precip }}(\% o$ ) and surface temperature $\left({ }^{\circ} \mathrm{C}\right)$ is shown for Greenland (a and b) and Antarctica (c and d). The relationship between $\delta^{18} \mathrm{O}_{\text {precip }}(\% o)$ and precipitation $\left(\mathrm{mm} \mathrm{day}^{-1}\right)$ is shown for the tropics (e and $\left.\mathbf{f}\right)$. Left panels: PI control simulation, right panels: LGM-combined simulation.

Over Greenland, the PI control run gave a spatial slope of $0.63 \% 0^{\circ} \mathrm{C}^{-1}$ (Fig. 6a). The slopes of the SST $\left(0.58 \% 0^{\circ} \mathrm{C}^{-1}\right)$, topography $\left(0.60 \% 0^{\circ} \mathrm{C}^{-1}\right)$ (not shown) and LGM-combined experiments (spatial slope of $0.54 \%{ }^{\circ} \mathrm{C}^{-1}$, Fig. 6b) deviated notably from the PI relationship.

Figure $6 \mathrm{e}$ and $\mathrm{f}$ show the relationship between the annual mean precipitation and $\delta^{18} \mathrm{O}_{\text {precip }}$, i.e. the amount effect over the tropics (from $20^{\circ} \mathrm{S}$ to $20^{\circ} \mathrm{N}$ ) for the PI control and LGM-combined simulations. Both experiments showed lower $\delta^{18} \mathrm{O}_{\text {precip }}$ values with an increase in the precipitation amount. This was also found for the other experiments (not shown). The modeled relation between total precipitation $(P)$ and $\delta^{18} \mathrm{O}_{\text {precip }}$ for the control experiment was $\delta^{18} \mathrm{O}_{\text {precip }}=-0.51 P-2.66 \%$ ( The GHG, albedo, topography and orbital experiments produced minor deviations in the range of $0.01-0.02 \%$ per $\mathrm{mm} \mathrm{day}^{-1}$ (not shown) from the spatial slope obtained for the control run. In contrast, spatial slopes of -0.60 and $-0.58 \%$ o per mm day ${ }^{-1}$ were found for the SST and LGM-combined experiments, respectively.

We used the results of our pre-industrial simulation to compare the spatial slope of $\delta^{18} \mathrm{O}_{\text {precip }}$ and surface temper- ature over Antarctica with the observational surface Antarctic snow composition data (Masson-Delmotte et al., 2008), and the present-day model simulations by Sime et al. (2008). For this, we regridded the annual mean results onto a $50 \mathrm{~km}$ equal-area grid (using only the continental grid cells as in Sime et al., 2008). The spatial relationships of $\delta^{18} \mathrm{O}_{\text {precip }}$ to the surface temperature were calculated for the entire Antarctic, East Antarctic and the West Antarctic regions. These regions were defined as per Sime et al. (2008). We obtained a slope of $0.54 \% 0^{\circ} \mathrm{C}^{-1}$ over the entire continent, where Masson-Delmotte et al. (2008) obtained $0.80 \%{ }^{\circ} \mathrm{C}^{-1}$. The spatial slope estimated for East Antarctica was $0.55 \%{ }^{\circ} \mathrm{C}^{-1}$, which is lower than the slope obtained from observations (Masson-Delmotte et al., 2008) and the modeled presentday slope of $0.73 \%{ }^{\circ} \mathrm{C}^{-1}$ by Sime et al. (2008). The slope for the West Antarctic region was estimated as $0.59 \% 0^{\circ} \mathrm{C}^{-1}$, whereas Sime et al. (2008) obtained a value of $1.28 \% 0^{\circ} \mathrm{C}^{-1}$. Over the entire Antarctic, changes with respect to the control run were simulated in the topography (spatial slope of $0.48 \% 0^{\circ} \mathrm{C}^{-1}$ ), SST (spatial slope of $0.48 \% 0^{\circ} \mathrm{C}^{-1}$ ), and LGM-combined (spatial slope of $0.45 \% 0^{\circ} \mathrm{C}^{-1}$ ) experiments (Fig. 6d). The albedo and GHG experiments yielded slopes that were identical to those in the control simulation. The precipitation simulated by the model for the PI control run was found to be larger by 10 to $20 \mathrm{~kg} \mathrm{~m}^{-2} \mathrm{yr}^{-1}$ when compared to the observations (cf. Masson-Delmotte et al., 2011). The overestimation of the surface temperature and the precipitation rate in the model over Antarctica may have contributed to the lack of depletion simulated by the model.

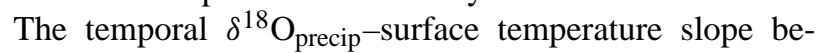
tween the PI and LGM-combined simulations calculated for Greenland was $0.51 \%{ }^{\circ} \mathrm{C}^{-1}$, which was about $19 \%$ smaller than the PI spatial slope. The temporal $\delta^{18} \mathrm{O}_{\text {precip-surface }}$ temperature slope between the PI and LGM-combined simulations for the entire Antarctic was $0.3 \% 0^{\circ} \mathrm{C}^{-1}$, which was $\sim 50 \%$ lower than the PI spatial slope. The temporal slope for the East Antarctic was $0.21 \%{ }^{\circ} \mathrm{C}^{-1}$, which was $\sim 60 \%$ lower than the PI spatial slope over the region, whereas for the West Antarctic the temporal slope was $22 \%$ lower $\left(0.46 \% 0^{\circ} \mathrm{C}^{-1}\right)$ than the PI spatial slope over the region.

\section{Seasonal signals in the sensitivity experiments}

\subsection{Seasonal cycle in control and LGM-combined climates}

In order to address the seasonal variations of $\delta^{18} \mathrm{O}_{\text {precip }}$ and the climate variables, the difference between boreal summer (June-August, JJA) and boreal winter (December-February, DJF) for surface temperature, $\delta^{18} \mathrm{O}_{\text {precip }}$ and precipitation were analyzed for the PI and LGM-combined simulations.

First, we analyzed the seasonal amplitude (JJA minus DJF) for the PI control simulation (Fig. 7). $\delta^{18} \mathrm{O}_{\text {precip values }}$ were higher (by 2 to $14 \%$ ) in the boreal summer (Fig. $7 \mathrm{~b}$ ) 

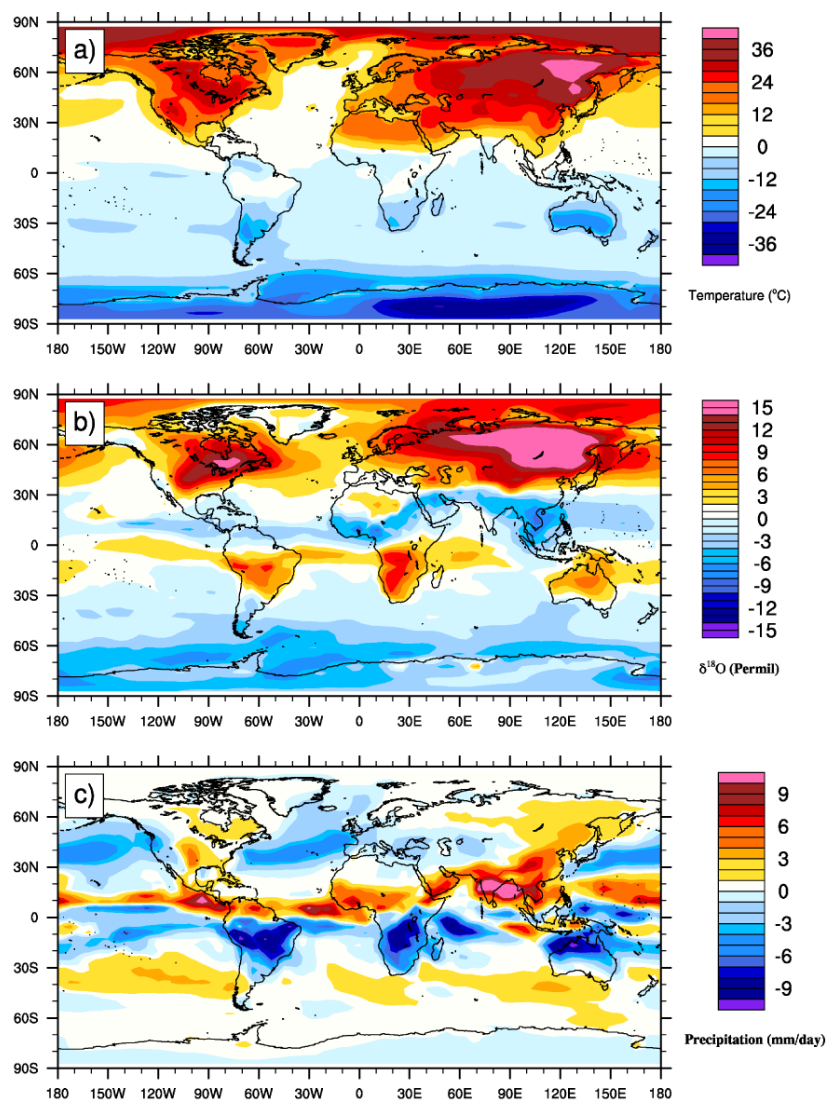

Fig. 7. The JJA-DJF difference of (a) surface temperature $\left({ }^{\circ} \mathrm{C}\right)$, (b) $\delta^{18} \mathrm{O}_{\text {precip }}(\%)$, and (c) total precipitation $\left(\mathrm{mm} \mathrm{day}^{-1}\right)$ of the control experiment.

compared to the winter season in the Northern Hemisphere, notably over North America and Eurasia, which may be due to the higher summer temperature (Fig. 7a). Lower values of $\delta^{18} \mathrm{O}_{\text {precip }}$ were simulated in the northern tropics during the boreal summer compared to boreal winter. This could be related to the amount effect, as suggested by the corresponding precipitation signature (Fig. 7c).

When contrasting the LGM-combined and PI seasonality (Fig. 8), the amplitude of the seasonal cycle of surface temperature over the northern latitudes $\left(>30^{\circ} \mathrm{N}\right)$, especially over Greenland, Eurasia and North America, was stronger in the LGM-combined simulation (Fig. 8a). For $\delta^{18} \mathrm{O}_{\text {precip }}$, the strength of the seasonal cycle in the control climate was larger over the Laurentide ice sheet, while over Eurasia the LGM seasonal amplitude was stronger (Fig. 8b). The seasonality of precipitation in the LGM climate was weaker as compared to the control climate over the monsoon regions and in higher latitudes. Over southern Africa and between $40^{\circ} \mathrm{N}$ and $50^{\circ} \mathrm{N}$ on the North American continent, the seasonal amplitude of precipitation was larger during the LGM (Fig. 8c), possibly because of a reduced winter (DJF) precipitation in the LGM-combined simulation when compared to the PI.

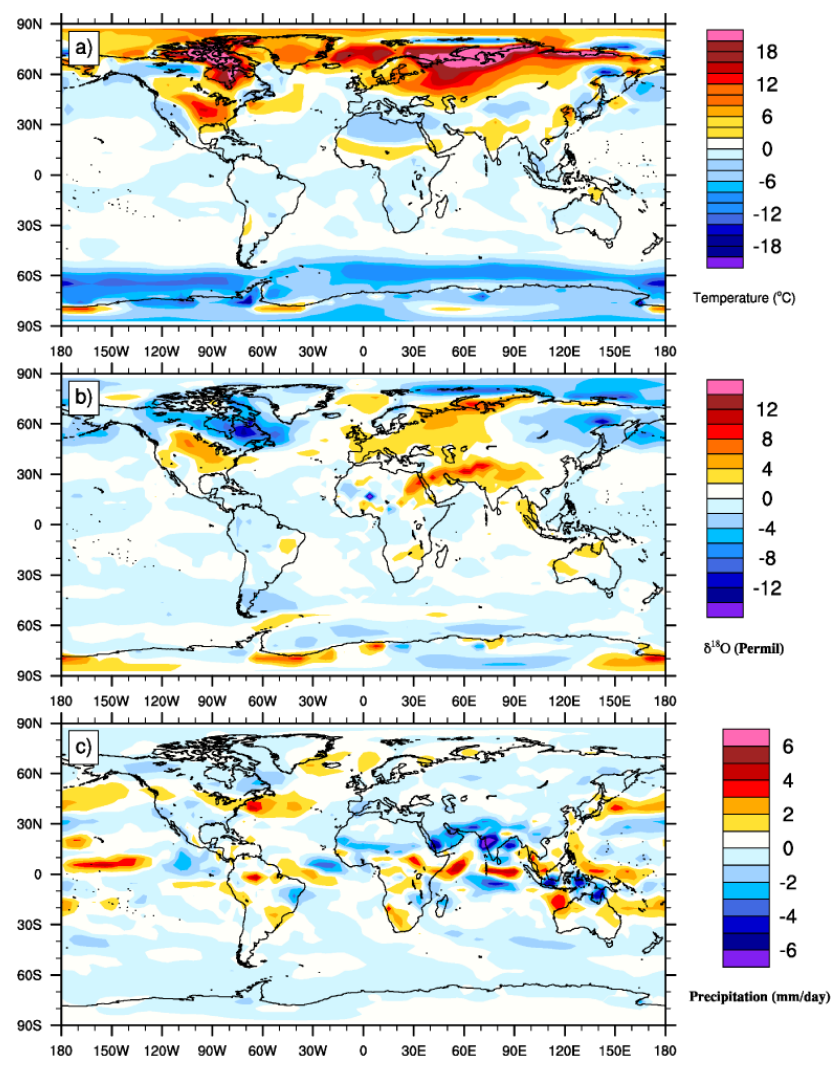

Fig. 8. The difference of (JJA-DJF) in LGM-combined experiment from the (JJA-DJF) in the control run (a) surface temperature $\left({ }^{\circ} \mathrm{C}\right)$, (b) $\delta^{18} \mathrm{O}_{\text {precip }}(\%)$, and (c) total precipitation $\left(\mathrm{mm} \mathrm{day}^{-1}\right)$.

\subsection{Seasonal response in the experiments in comparison with PI}

Atmospheric general circulation features such as monsoons or the seasonal migration of the Intertropical Convergence Zone (ITCZ) are reflected in the distribution of $\delta^{18} \mathrm{O}_{\text {precip. }}$. The isotopic ratio of summer precipitation is much lower than that of winter precipitation and leads to lower summer $\delta^{18} \mathrm{O}_{\text {precip }}$ values in connection with the precipitation amount, especially in the tropics (seasonality and amount effect of isotopes, Dansgaard, 1964). Therefore, in this section, we analyze the seasonal response of $\delta^{18} \mathrm{O}_{\text {precip }}$ in the individual experiments with respect to the PI control climate. The winter and summer anomalies of $\delta^{18} \mathrm{O}_{\text {precip }}$ are shown in Figs. 9 and 10, respectively.

Lower $\delta^{18} \mathrm{O}_{\text {precip }}$ values were simulated in the Northern Hemisphere in the topography, SST and LGM-combined simulations in the DJF and JJA seasons (Figs. 9 and 10 respectively) when compared to the control simulation, which could be a result of the temperature effect due to the reduced SST and the changes in the atmospheric circulation brought about by the topography changes. In the DJF season, $\delta^{18} \mathrm{O}_{\text {precip }}$ values were lowered by 5 to $10 \%$ over western Antarctica in the topography, LGM-combined and SST 

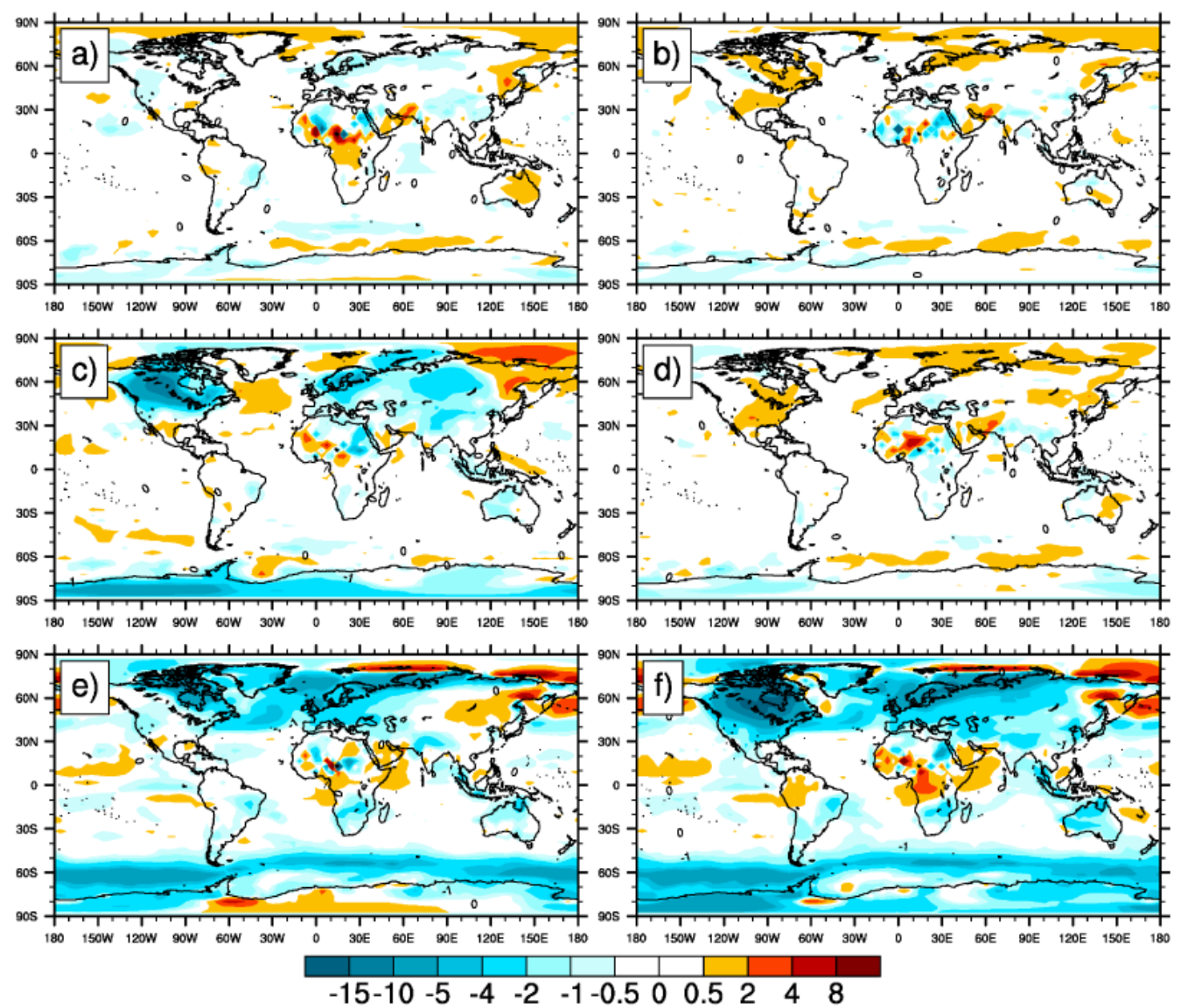

Fig. 9. The anomalies of $\delta^{18} \mathrm{O}_{\text {precip }}(\%)$ for (a) GHG, (b) albedo, (c) topography, (d) orbital, (e) SST, and (f) LGM-combined experiments from the control experiment for the boreal winter (DJF).

experiments. The albedo experiment produced lower summertime $\delta^{18} \mathrm{O}_{\text {precip }}$ values over North America, and the response was stronger than in winter. The topography experiment produced higher $\delta^{18} \mathrm{O}_{\text {precip }}$ values in the south of the North American continent. Higher $\delta^{18} \mathrm{O}_{\text {precip }}$ values were simulated over central Antarctica in the SST experiment, both in winter and summer. It should be noted that the direct influences of GHG forcing provided a minimal response in both winter and summer seasons over land. The higher $\delta^{18} \mathrm{O}_{\text {precip }}$ values in the boreal summer in the SST and LGMcombined simulations over Africa and South Asia were correlated with the reduced summer monsoon intensity (not shown) in these experiments.

\subsection{Isotopic content of the atmospheric water vapor}

The isotopic ratio in precipitation depends on the isotopic content of the atmospheric water vapor, which in turn changes with the atmospheric circulation. In the present study, the topography and LGM-combined experiments produced the greatest changes in the atmospheric circulation and seasonal distribution of the $\delta^{18} \mathrm{O}$ content of the water vapor.
Therefore, we focus on these experiments in the remainder of this section.

The isotopic content of water vapor at the $500 \mathrm{hPa}$ level showed a wintertime depletion (Fig. 11) over the ice sheets in the topography experiment compared to the control run. The $500 \mathrm{hPa}$ geopotential height field showed a split over the Laurentide ice sheet in the flow due to the topography, in agreement with previous LGM modeling experiments (Otto-Bliesner et al., 2006a). A trough in the geopotential height field indicated enhanced storm activity over Eurasia and the North Atlantic in the winter season of the LGMcombined simulation (Fig. 11a), with a ridge over western North America and a trough over the east of the continent. The more westerly winds over central and northern Greenland in winter, and also the remote moisture transport from North America with lower $\delta^{18} \mathrm{O}$ values relative to a North Atlantic source, caused lower $\delta^{18} \mathrm{O}$ values in the water vapor over Greenland. In contrast, higher $\delta^{18} \mathrm{O}$ values in water vapor were found over the North Pacific and over eastern Eurasia where southeasterly wind anomalies were simulated with respect to the PI experiment. Another feature of the $500 \mathrm{hPa}$ winter circulation was enhanced transpolar winds 

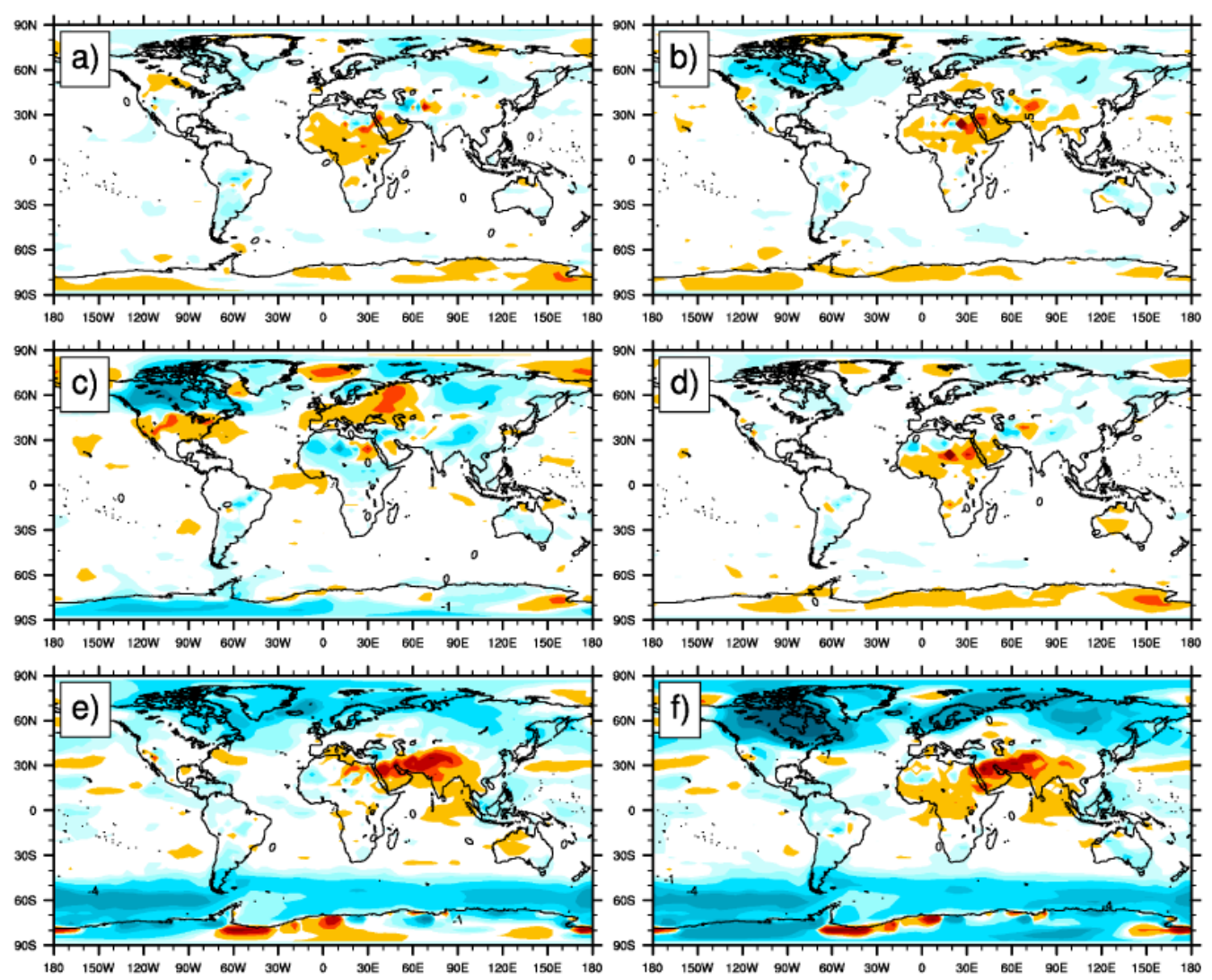

$\begin{array}{lllllllllllllllllll}-15-10 & -5 & -4 & -2 & -1 & -0.5 & 0 & 0.5 & 2 & 4 & 8\end{array}$

Fig. 10. As Fig. 9, but for JJA season.

from Eurasia to the northeastern part of the North American continent in the topography as well as in the LGM-combined experiment. Higher $\delta^{18} \mathrm{O}$ values in winter over the central North Pacific in the topography experiment (Fig. 11b middle) were absent from the LGM-combined experiment (Fig. 11b bottom).

In the summer season (Fig. 12), higher $\delta^{18} \mathrm{O}$ in water vapor were simulated over Greenland and northwestern Eurasia, and lower $\delta^{18} \mathrm{O}$ in water vapor were simulated over the Laurentide ice sheet in the LGM-combined experiment when compared with the control run (Fig. 12b bottom). Higher $\delta^{18} \mathrm{O}$ values in water vapor over Eurasia and over the Laurentide ice sheet were seen in the topography experiment. Also, the circulation from Eurasia and the North Atlantic to central and southern Greenland was strengthened due to stronger eddy activity, along with a strengthening of the circumpolar winds (Fig. 12b middle). The $500 \mathrm{hPa}$ wintertime circulation responses over North America were similar in the LGMcombined and the topography simulations, whereas the summer circulation in the LGM-combined was distinct from the topography experiment. These differences in the summer circulation were reflected as opposite signals in the pattern of the $\delta^{18} \mathrm{O}$ in vapor (higher $\delta^{18} \mathrm{O}$ values in the topography experiment and lower $\delta^{18} \mathrm{O}$ values in the LGM-combined experiment) over northeast and central North America.

\section{Discussion}

To understand the changes in $\delta^{18} \mathrm{O}_{\text {precip }}$ between the PI and LGM, a sequential procedure was used to isolate the influence of the different LGM boundary conditions on climate. The experiments enable an examination of the dependence of the $\delta^{18} \mathrm{O}_{\text {precip }}$ distribution on different aspects of the atmospheric circulation and precipitation regime that result from the various climate forcing factors.

\subsection{Simulated climates}

The climate in our LGM-combined and PI control experiments was similar to results from existing coupled atmosphere-ocean model simulations (Otto-Bliesner et al., 2006a; Merkel et al., 2010). This was in line with the observation from fixed-SST atmospheric model studies by, for example, Timbal et al. (1997) and Mahfouf et al. (1994) that an atmospheric GCM forced by SST anomalies from a coupled model run can reproduce the general features of the 

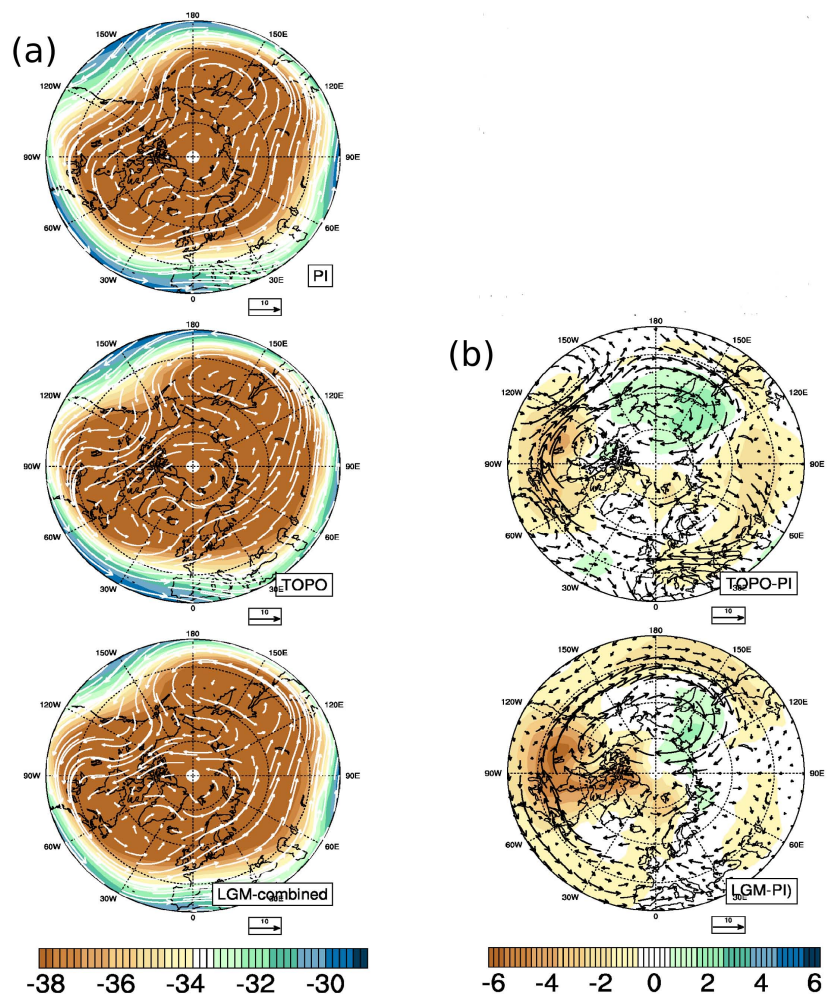

Fig. 11. $500 \mathrm{hPa}$ winter (DJF) circulation. Left panels: $\delta^{18} \mathrm{O}(\%)$ in the vapor and wind vectors $\left(\mathrm{m} \mathrm{s}^{-1}\right)$ overlaid for the PI, topography and LGM-combined experiments; right panels: the difference of the same from the PI control run.

atmospheric response obtained by the coupled model. The specification of SST at the lower boundary of an atmospheric GCM has the advantage that the atmosphere equilibrates in a few months with the prescribed SSTs. However, prescribing SSTs led to an annual global energy imbalance at the top of the model and the surface, and the largest effects were seen in the surface energy budgets. The surface temperature and precipitation patterns in the PI and LGM-combined simulations were nearly identical to those of the fully coupled model, so we expect the simulations to produce consistent mean atmospheric states in response to the forcings, and the anomalies from the control climate to be robust. When compared to the PI simulation, the global annual mean latent heat flux is reduced in all the experiments except the GHG simulation, which in turn balances the decreased global annual mean precipitation.

A change in the albedo alters the absorption and reflection of solar radiation. The albedo effect of the ice sheets is more prominent in the boreal summer months than in the winter months, with a strong reduction of summer surface temperature over North America and Eurasia and a corresponding depletion of $\delta^{18} \mathrm{O}_{\text {precip }}$. The surface temperature gradient between the ice sheets and the adjacent ice-free areas produced increased summer precipitation over the south-
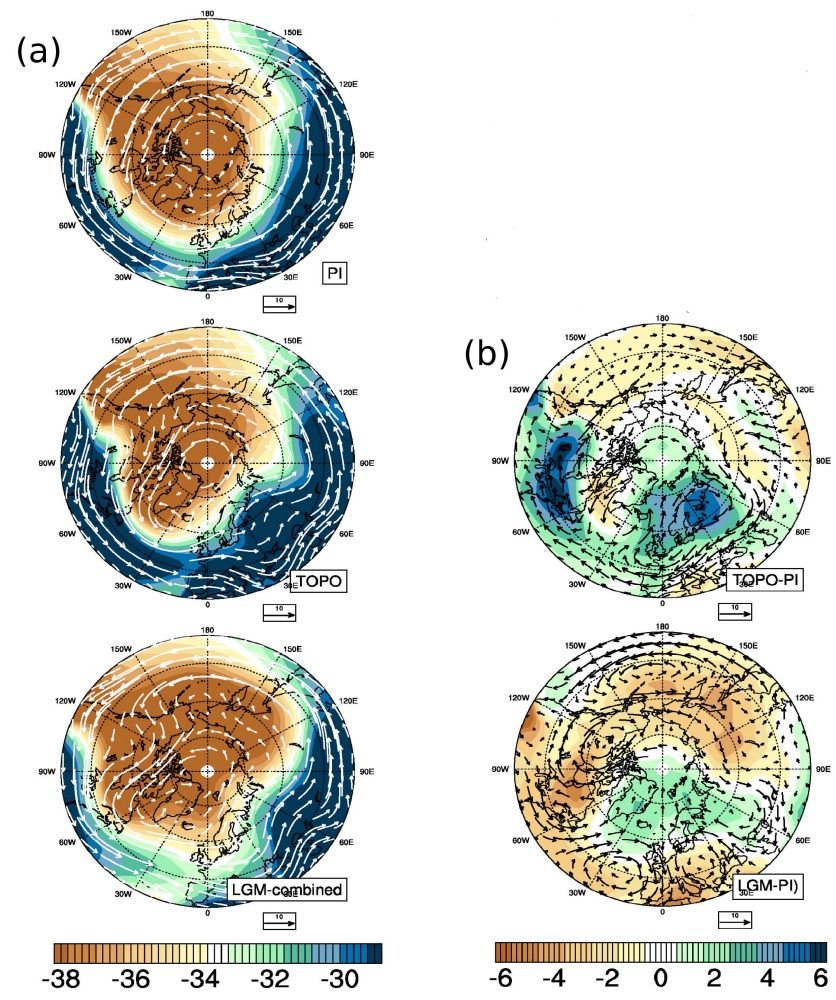

Fig. 12. As Fig. 11, but for JJA season.

ern part of North America and the western North Atlantic as also noted by Manabe and Broccoli (1985).

In the topography experiment a localized reduction of surface temperature and more depleted values of $\delta^{18} \mathrm{O}_{\text {precip were }}$ simulated due to drier conditions over the elevated orography. The altitude effect contributed to the lower isotope ratios. The effects of the ice sheet topography were mainly confined to the Northern Hemisphere high latitudes, as an inter-hemispheric heat transport via ocean currents is missing in the experiments. The resulting cooling was much smaller than that obtained by Hewitt and Mitchell (1997), who use an atmospheric general circulation model coupled to a mixedlayer ocean model.

Qualitatively, our results for the topography experiment match those obtained by Pausata et al. (2011a) with a coupled atmosphere-ocean model, who also obtain a warming over southern North America and western Europe in response to the elevated orography, but on a larger scale.

The global mean temperature change of the orbital experiment was the smallest among all the simulations, which was expected as the orbital parameters for the present day and the LGM are quite similar. The SST played a decisive role in the reduction of tropical surface air temperature and precipitation and consequently led to higher $\delta^{18} \mathrm{O}_{\text {precip values }}$ in the SST experiment, which could thus be interpreted as a direct effect of the SST on the tropical climate. Pausata et al. (2011b) similarly find that changes in the Indian Ocean 
SST alone lead to a decrease in precipitation over the Indian Ocean and subcontinent, hence producing higher $\delta^{18} \mathrm{O}_{\text {precip }}$ values over southern and eastern Asia. The global mean cooling brought about by the SST experiment accounted for $67 \%$ of the total temperature reduction in the LGM-combined experiment, which clearly demonstrated the importance of the ocean forcing.

The precipitation decreased substantially in the LGMcombined simulation, particularly in the ITCZ and the monsoon regions as seen in previous studies (e.g. Shin et al., 2002).

In summary, the experiments showed that the SST and topography changes brought about considerable changes in the annual mean surface temperature and distribution of

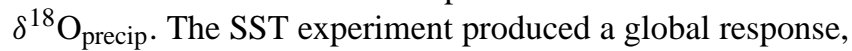
whereas the topography and ice sheet albedo had more local effects on climate and hence the $\delta^{18} \mathrm{O}_{\text {precip }}$ distribution.

\subsection{Regional annual mean of $\delta^{18} \mathrm{O}_{\text {precip }}$}

From the regional annual means of $\delta^{18} \mathrm{O}_{\text {precip }}$ over the different geographical regions (Table 6), we infer that each factor produced unique changes in the isotope signals over different regions. The albedo, topography and SST changes were the major factors influencing the annual mean $\delta^{18} \mathrm{O}_{\text {precip }}$ over the Laurentide ice sheets. For Greenland and Antarctica, the reduction in SST and the change in topography were the dominant factors that led to more depleted values compared to the PI simulation. The topography and SST effects explained most of the LGM depletion over Antarctica.

The regional annual mean of $\delta^{18} \mathrm{O}_{\text {precip }}$ over the North American ice sheets for the LGM-combined experiment is $-24 \%$ (Table 6), which is less depleted compared to the approximate value of $-31 \%$ derived for the Laurentide ice sheet (Duplessy et al., 2002). A lowering by $10 \%$ o of $\delta^{18} \mathrm{O}_{\text {precip }}$ values was produced over the Laurentide ice sheet in the LGM-combined experiment. The topography change alone brought about lower $\delta^{18} \mathrm{O}_{\text {precip }}$ values of $3 \%$ o over North America, while albedo and SST changes reduced $\delta^{18} \mathrm{O}_{\text {precip }}$ by $1 \%$ o each. The altitude effect (Dansgaard, 1964) in the topography experiment was evident from the difference to the ice sheet albedo experiment.

The mean value of $-17 \%$ in the LGM-combined experiment over Eurasia was comparatively high with respect to the range of -16 to $-40 \%$ o proposed by Duplessy et al. (2002). The annual mean difference of $-2.2 \%$ between the LGMcombined and PI experiments over Greenland (Table 6) was smaller than the difference of -6 to $-8 \%$ in $\delta^{18} \mathrm{O}_{\text {precip }}$ obtained from GRIP/GISP2 estimates (Werner et al., 2000, and references therein). The difference of $\delta^{18} \mathrm{O}_{\text {precip }}$ between the LGM-combined and PI experiments over central Greenland of $-2.67 \%$ was smaller than the difference of $-4.1 \%$ modeled for the summit region by Werner et al. (2001). The difference in annual mean surface temperature between the LGM-combined and PI experiments over central Greenland $\left(-13.96^{\circ} \mathrm{C}\right)$ was smaller than the reconstructed value from the borehole thermometry (approximately $-23^{\circ} \mathrm{C}$; Cuffey and Clow, 1997). Thus, the overestimation of surface temperature over Greenland in the model could explain the heavier $\delta^{18} \mathrm{O}_{\text {precip }}$ value.

Over northern and southern South America, the annual mean depletion was stronger in the SST and LGM-combined experiments compared to the control climate. Previous studies (Clapperton, 1993; Thompson et al., 2000) suggest a drier climate over South America during the LGM (25\% of land classified as desert), with colder tropical oceans and weaker inflow of moisture from the ocean. The response of the $\delta^{18} \mathrm{O}_{\text {precip }}$ to the LGM-combined and LGM-SST forcing hints at the influence of the Atlantic Ocean, Pacific Ocean and Caribbean Sea, which are the major sources of moisture for this continent (Rozanski and Araguas-Araguas, 1995). Sylvestre (2009) suggests prevailing drier conditions in northern South America and a wetter southern part of the continent. The apparent shift in ITCZ and the wetter zones along with a less supply of moisture with higher $\delta^{18} \mathrm{O}_{\text {precip }}$ composition from the ocean are expected to be the reason for more depleted values simulated in southern South America than in northern South America. Over northern Africa, higher annual mean $\delta^{18} \mathrm{O}_{\text {precip }}$ values were simulated in all simulations in spite of small anomalies in precipitation, and the corresponding slopes in the precipitation$\delta^{18} \mathrm{O}_{\text {precip }}$ relationships for all the experiments were higher (by 0.1 to $0.2 \% \mathrm{~mm}^{-1} \mathrm{day}^{-1}$ ) than for the PI experiment $\left(-0.69 \% \mathrm{~mm}^{-1} \mathrm{day}^{-1}\right)$, except for the topography experiment. These changes were consistent with the amount effect, as was also reported by Risi et al. (2010) for western Africa. There may be different reasons for the negative precipitation anomalies over western Africa in the individual experiments. It was found that the ice sheet albedo in LGM is responsible for the changes in the subtropical trade wind pattern and a southward shift of the ITCZ (Chiang et al., 2003). However, the precipitation anomalies could also result from a poor representation of surface temperature and precipitation in our model over this region (Levis et al., 2004; Deser et al., 2005; Meehl et al., 2006). When compared the model results with observed data (GNIP; IAEA/WMO, 2006), it was found that the model in general underestimated $\delta^{18} \mathrm{O}_{\text {precip }}$ in arid regions such as northern Africa, thus a small reduction in precipitation could have caused an exaggerated increase in isotope ratios. Finally, the model is comparatively colder over northern Africa, while it overestimates the precipitation in the southern parts when compared to observations.

The simulated annual mean anomaly of $\delta^{18} \mathrm{O}_{\text {precip }}$ over Antarctica in the LGM-combined experiment agrees reasonably well with the reconstructed difference of 3 to $5 \%$ compared to the present-day value in the Vostok ice core (Lorius et al., 1985). 


\subsection{Spatial relationship of $\delta^{18} \mathrm{O}_{\text {precip }}$ with surface temperature and precipitation}

The $\delta^{18} \mathrm{O}_{\text {precip }}$-surface temperature relationship simulated in the PI experiment over Greenland has a slope that is slightly smaller (by $0.06 \% 0^{\circ} \mathrm{C}^{-1}$ ) compared to observations (Johnsen et al., 1989, $\delta^{18} \mathrm{O}=0.67 \% 0^{\circ} \mathrm{C}^{-1} T-13.7 \%$, $T$ in ${ }^{\circ} \mathrm{C}$ ) and results from the ECHAM3 (Werner et al., 2000) and the CAM2 (Lee et al., 2007) atmosphere models. In our LGM-combined experiment, the spatial slope was reduced by $0.09 \%{ }^{\circ} \mathrm{C}^{-1}$ over Greenland. Generally, the spatial slopes obtained for the control and LGM climates were similar, as in the results obtained by, for example, Jouzel et al. (1994).

The slope of the $\delta^{18} \mathrm{O}_{\text {precip }}$-surface temperature relationship over Antarctica in the PI simulation $\left(0.54 \% 0^{\circ} \mathrm{C}^{-1}\right)$ deviates from the observations by Dahe et al. (1994), who derive a slope of $0.84 \% 0^{\circ} \mathrm{C}^{-1}$, and by Masson-Delmotte et al. (2008) with a result of $0.80 \% 0^{\circ} \mathrm{C}^{-1}$. The inability of isotope models to accurately simulate the present-day distribution of isotopes over the southern polar regions and the failure to reproduce the inland depletion was discussed in Werner et al. (2000) and Lee et al. (2007). The underestimation of isotopic depletion over Antarctica is suggested to be related to the representation of the cloud microphysics in these models and their representation of the transport of moisture inland (Masson-Delmotte et al., 2008). The reduced slope over Antarctica in our results points to less depletion of isotopes in precipitation with lower temperature in the model over the continent. The warm bias in our model over Antarctica could also be a contributing factor to the lack of the lowest $\delta^{18} \mathrm{O}_{\text {precip }}$ values observed in polar snow.

The tropical amount effect was evident in all our simulations and the slope obtained for the control run was comparable in magnitude with the slope derived from the observed values at the tropical marine stations selected from the GNIP database $\left(-0.55 \%\right.$ o per $\mathrm{mm} \mathrm{day}^{-1}$, Bony et al., 2008; Cole et al., 1999). Except for the SST and LGM-combined experiments, the changes in the $\delta^{18} \mathrm{O}_{\text {precip-precipitation relation- }}$ ship were negligible, mostly due to the fixed SSTs.

The spatial and temporal slopes for Greenland were relatively close when the difference between the LGM-combined and PI simulations was considered (the temporal slope differed by about $\sim 19 \%$ from the spatial slope). Temperature profiles from borehole thermometry (Cuffey et al., 1994, Jouzel et al., 1997) and temperature estimates from the thermal fractionation of gases (Severinghaus et al., 1998; Severinghaus and Brook, 1999) indicate that the temporal slope over Greenland was about half of the spatial slope. A modeling study by Werner et al. (2000), who obtain a temporal slope smaller by $60 \%$ than the spatial slope, attributes this change to the seasonality in glacial precipitation (strongly reduced winter precipitation) over Greenland. We suggest that the absence of a distinct seasonality in precipitation under PI as well as glacial conditions over Greenland in our results led to similar spatial and temporal slopes. The temporal slope obtained over East Antarctica was about half the spatial slope, as also seen in the modeling study by Lee et al. (2008). The reduced winter precipitation in the LGM and the changes in the glacial topography and consequent reduction in surface temperature in West Antarctica could have resulted in the change of the glacial-PI temporal slope. Lee et al. (2008) suggest that the value of the temporal slope is related to the temperature decrease over the Southern Ocean. Comparison of the temporal slopes with that obtained by the modeling studies of Werner et al. (2000) and Lee et al. (2008) suggests that the slopes obtained could be model dependent.

\subsection{Seasonal cycle of $\delta^{18} \mathrm{O}_{\text {precip }}$}

As Jouzel et al. (1987) noted for the present-day climate, the seasonal cycle of $\delta^{18} \mathrm{O}_{\text {precip }}$ is divided at $30^{\circ}$ of latitude, where the zero contour was also found in all our experiments (Figs. $7 \mathrm{~b}$ and 8b). Observations show that poleward of this latitude the seasonal contrast is stronger and the maximum enrichment in the summer of the respective hemispheres is largest (Feng et al., 2009). These latitudes coincide with regions of strong evaporation and little precipitation due to subsiding air masses. Furthermore, the precipitation in these latitudes is enriched in heavy isotopes because of the proximity to the source regions. It has been argued that the seasonality of isotopes between $20^{\circ} \mathrm{S}$ and $20^{\circ} \mathrm{N}$ reflects the atmospheric circulation and that the isotopic minima and maxima in the different seasons represent the positions of the ITCZ (Feng et al., 2009).

The seasonal anomalies of $\delta^{18} \mathrm{O}_{\text {precip }}$ in the simulations show that the influence of the climate factors varies with the seasons. The largest response in $\delta^{18} \mathrm{O}_{\text {precip }}$ to the ice sheet albedo was simulated in boreal summer. The higher summertime $\delta^{18} \mathrm{O}_{\text {precip }}$ values produced over the tropical monsoon regions in the SST and LGM-combined simulations are also evidence of the dominance of the rainy season on the annual signal and of the relative importance of SST in the distribution of $\delta^{18} \mathrm{O}_{\text {precip }}$ over the region. The higher $\delta^{18} \mathrm{O}_{\text {precip }}$ values simulated in the summer season of the LGM-combined experiment are in agreement with previous studies indicating a weaker southwest summer monsoon during the LGM (Manabe and Broccoli, 1985; Van Campo, 1986; Kutzbach and Guetter, 1986; Rind, 1987; Lautenschlager and Santer, 1991), and at the same time, the ITCZ likely shifted southward.

The absence of a strong seasonality in the precipitation rate over Antarctica found in our experiments was also reported in Cuffey et al. (1997). A similar lack of definite seasonality in precipitation and in isotope distribution over Greenland was found in all the simulations. The SST experiment brought about the largest change in the $\delta^{18} \mathrm{O}_{\text {precip }}$ distribution over Greenland, both in winter and summer, while the topography experiment produced more depleted $\delta^{18} \mathrm{O}_{\text {precip }}$ values in summer, when compared to the control experiment. 


\subsection{Changes in the atmospheric circulation}

It is suggested that the atmospheric circulation in the LGM was considerably different from the present-day configuration, owing to the elevated ice sheet orography and increased sea ice in high latitudes (Broccoli and Manabe, 1987a; Shin et al., 2002; Otto-Bliesner et al., 2006a). Pausata et al. (2011a) conclude that the ice sheet topography in the LGM plays a dominant role in altering the large-scale atmospheric circulation, particularly over the North Atlantic Ocean. Distinct changes in the northern high-latitude circulation were indeed simulated in our topography and LGMcombined experiments with associated differences in the distribution of $\delta^{18} \mathrm{O}$ in vapor.

Previous studies (Charles et al., 1994; Werner et al., 2001) identify the nearby polar seas, the North Atlantic and North Pacific Oceans and the North American and Eurasian continents as the moisture source regions for glacial Greenland precipitation. When compared to modern conditions, the ice sheets caused a significant reduction of the contribution of moisture from North America, particularly the region covered by the ice sheets. Werner et al. (2001) also find a southward shift of moisture transport from the North Atlantic and North America to Greenland. Kageyama and Valdes (2000) suggest that in Greenland the winter precipitation during the LGM is lower because of the changes in atmospheric circulation and the southward deviation of the storm tracks due to the Laurentide ice sheet, extended sea ice, and also because of the modified latitudinal SST gradient. The drier air mass advected over Greenland causes less precipitation during the winter season in the north. The drier air mass over the ridge in the $500 \mathrm{hPa}$ geopotential height field (not shown) near the margin of the Laurentide ice sheet may have led to more depleted $\delta^{18} \mathrm{O}$ in vapor values during winter in both the topography and LGM-combined simulations. The increased northerly flows and trans-polar advection of colder and drier air masses at the $500 \mathrm{hPa}$ level in the LGM-combined experiment would also have contributed to the drier conditions and more depleted $\delta^{18} \mathrm{O}$ in vapor values during the DJF season. When comparing responses of $\delta^{18} \mathrm{O}$ in vapor to the topography and the LGM-combined forcing, they are very similar over North America during DJF and opposite during JJA. This indicates that the ice sheet albedo was the major controlling factor during summer. Pausata et al. (2011a) also find a relatively larger effect of albedo on the upper tropospheric winds in summer. The enrichment of heavy isotope ratios in vapor in the mid-troposphere seen in the JJA season of the LGM-combined and topography simulations over Greenland could be attributed to the advection of enriched water vapor from the North Atlantic and Eurasia, which agrees with Charles et al. (1994), while the North Pacific source of moisture for northern Greenland was not evident in our results.

\section{Conclusions}

Our experiments allowed for an assessment of the effect of the individual climatic boundary conditions on the climate of the LGM, although a complete factor separation analysis (Stein and Alpert, 1993) was beyond the scope of this study. The focus was on the spatial pattern of the climate and corresponding isotopic response and to a lesser degree on its magnitude. We suppressed the feedbacks from the ocean and sea ice by using fixed SSTs derived from previous simulations of a coupled atmosphere-ocean model, which allowed the response to the LGM SST to be considered as a separate factor. This methodology had the advantage of largely isolating the effect of the individual forcing factors (particularly albedo, ice sheet topography and insolation changes) on the atmosphere without the response being dominated by the SST feedback. We note, however, that quantitative aspects of the response to the individual forcing factors in a fully coupled model are likely to be different from our results.

Our simulations indicate that the changes in topography due to the large continental ice sheets and the changes in SST were the two predominant factors determining the distribution of oxygen isotopes in precipitation. The altitude effect and the changes in atmospheric circulation brought about by the LGM topography led to a depletion of $\delta^{18} \mathrm{O}_{\text {precip }}$ in the high latitudes of the Northern Hemisphere. Overall, the albedo and topography of the ice sheets have a local effect on the surface temperature and precipitation, and the distribution of $\delta^{18} \mathrm{O}_{\text {precip }}$ appears to be influenced by these local changes in surface temperature. The lower SST was the dominant factor in reducing the precipitation in the tropical regions, which in turn led to higher $\delta^{18} \mathrm{O}_{\text {precip values in sum- }}$ mer. Treating the SST as a separate forcing factor helped to understand the isotopic response, particularly in the tropics.

The relationship between $\delta^{18} \mathrm{O}_{\text {precip }}$ and surface temperature and $\delta^{18} \mathrm{O}_{\text {precip }}$ and precipitation was rather insensitive to changes from PI to full LGM boundary conditions. A strong seasonality was lacking in the surface distribution of $\delta^{18} \mathrm{O}_{\text {precip }}$ and precipitation over Greenland in all the simulations. The LGM-topography and LGM-combined simulations produced substantial changes in the tropospheric circulation. The changes in atmospheric circulation led to a drying and more depleted $\delta^{18} \mathrm{O}$ in vapor in the LGM-combined simulation during boreal winter. In contrast, the summer circulation showed an enhanced southerly flow from the North Atlantic to Greenland with enriched vapor. The increased summertime southerly moisture transport from the North Atlantic to Greenland in the LGM-combined experiment hints that it could be a major source of moisture for Greenland during the LGM. The role of the North Atlantic SST in causing changes in the atmospheric circulation near Greenland could be small, as the $500 \mathrm{hPa}$ anomalies in the $\delta^{18} \mathrm{O}$ in vapor in the SST experiment were small and even opposite in sign when compared to the anomalies of the LGM-combined simulation. An isotopic seasonality related to the precipitation 
amount effect is found over the tropical monsoon regions in our LGM-combined and SST simulations, where the colder and drier Asian continent during the LGM caused a reduction of the land-sea temperature gradient and hence of the intensity of the SW monsoon. Future studies should include at least a mixed-layer ocean model to account for the oceanatmosphere feedback, as well as a possibility to tag the water vapor from different source regions.

\section{Supplementary material related to this article is available online at: http://www.clim-past.net/9/789/2013/ cp-9-789-2013-supplement.zip.}

Acknowledgements. This project was funded by the DFG (Deutsche Forschungsgemeinschaft) within the European Graduate College "Proxies in Earth History." In addition, AP and UM acknowledge the support of MARUM - Center for Marine Environmental Sciences.

Edited by: U. Mikolajewicz

\section{References}

Berger, A.: Long-term variations of daily insolation and Quaternary climatic changes, J. Atmos. Sci., 35, 2362-2367, 1978.

Bonan, G. B., Oleson, K. W., Vertenstein, M., Levis, S., Zeng, X., Dai, Y., Dickinson, R. E., and Yang, Z.-L.: The land surface climatology of the Community Land Model coupled to the NCAR Community Climate Model, J. Climate, 15, 3123-3149, 2002.

Bony, S., Risi, C., and Vimeux, F.: Influence of convective processes on the isotopic composition $\left(\delta^{18} \mathrm{O}\right.$ and $\left.\delta \mathrm{D}\right)$ of precipitation and water vapor in the tropics: 1 . Radiative-convective equilibrium and TOGA-COARE simulations, J. Geophys. Res., 113, D19305, doi:10.1029/2008JD009942, 2008.

Braconnot, P., Otto-Bliesner, B., Harrison, S., Joussaume, S., Peterchmitt, J.-Y., Abe-Ouchi, A., Crucifix, M., Driesschaert, E., Fichefet, Th., Hewitt, C. D., Kageyama, M., Kitoh, A., Laîné, A., Loutre, M.-F., Marti, O., Merkel, U., Ramstein, G., Valdes, P., Weber, S. L., Yu, Y., and Zhao, Y.: Results of PMIP2 coupled simulations of the Mid-Holocene and Last Glacial Maximum Part 1: experiments and large-scale features, Clim. Past, 3, 261277, doi:10.5194/cp-3-261-2007, 2007.

Braconnot, P., Harrison, S. P., Kageyama, M., Bartlein, P. J., Masson-Delmotte, V., Abe-Ouchi, A., Otto-Bliesner, B., and Zhao, Y.: Evaluation of climate models using palaeoclimatic data, Nat. Clim. Change, 2, 417-424, 2012.

Broccoli, A. J. and Manabe, S.: The effects of the Laurentide ice sheet on north American climate during the last glacial maximum, Géographie physique et Quaternaire, 41, 291-299, 1987a.

Broccoli, A. J. and Manabe, S.: The influence of continental ice, atmospheric $\mathrm{CO}_{2}$, and land albedo on the climate of the last glacial maximum, Clim. Dynam., 1, 87-99, 1987b.

Charles, C. D., Rind, D., Jouzel, J., Koster, R. D., and Fairbanks, R. G.: Glacial-interglacial changes in moisture sources for Greenland: influences on the ice core record of climate, Science, 263, 508-511, 1994.
Chiang, J. C. H., Biasutti, M., and Battisti, D. S.: Sensitivity of the Atlantic ITCZ to Last Glacial Maximum boundary conditions, Paleoceanography, 18, 1094, doi:10.1029/2003PA000916, 2003.

Clapperton, C. M.: Nature of environmental changes in South America at the Last Glacial Maximum, Palaeogeogr. Palaeocli., 101, 189-208, 1993.

Cole, J. E., Rind, D., Webb, R. S., Jouzel, J., and Healy, T.: Climatic controls on interannual variability of precipitation $\delta^{18} \mathrm{O}$ : The simulated influence of temperature, precipitation amount, and vapour source region, J. Geophys. Res., 104, 14223-14235, 1999.

Collins, W. D., Rasch, P. J., Boville, B. A., Hack, J. J., McCaa, J. R., Williamson, D. L., Kiehl, J. T., Briegleb B., Bitz, C. M., Lin, S. J., Zhang, M., and Dai, Y.: Description of the NCAR Community Atmosphere Model (CAM3.0). NCAR Technical Note NCAR/TN-464+STR, National Center for Atmospheric Research, Boulder, Colorado, 214 pp., available at: http://www. ucar.edu/library/collections/technotes/technotes.jsp, 2004.

Collins, W. D., Rasch, P. J., Boville, B. A., Hack, J. J., McCaa, J. R., Williamson, D. L., and Briegleb, B.: The formulation and atmospheric simulation of the Community Atmospheric Model version 3 (CAM3), J. Climate, 19, 2144-2161, 2006.

Craig, H. and Gordon, L. I.: Deuterium and oxygen 18 variations in the ocean and marine atmosphere, in: Proc. Stable Isotopes in Oceanographic Studies and Paleotemperatures, 9-130, 1965.

Cuffey, K. M. and Clow, G. D.: Temperature, accumulation, and ice sheet elevation in central Greenland through the last deglacial transition, J. Geophys. Res., 102, 26383-26396, 1997.

Cuffey, K. M., Alley, R. B., Grootes, P. M., Bolzan, J. M., and Anandakrishnan, S.: Calibration of the $\delta^{18} \mathrm{O}$ isotopic paleothermometer for central Greenland using borehole temperatures, J. Glaciol., 40, 341-349, 1994.

Dahe, Q., Petit, J. R., Jouzel, J., and Stievenard, M.: Distribution of stable isotopes in surface snow along the route of the 1990 International Trans-Antarctica Expedition, J. Glaciol., 40, 107118, 1994.

Dahl-Jensen, D., Mosegaard, K., Gundestrup, N., Clow, G. D., Johnsen, S., Hansen, A. W., and Balling, N.: Past temperature directly from the Greenland Ice Sheet, Science, 282, 268-271, 1998.

Dansgaard, W.: Stable Isotopes in Precipitation, Tellus, 16, 436468, 1964.

Dansgaard, W., Johnsen, S. J., Clausen, H. B., and Gundestrup, N.: Stable isotope glaciology, Meddelelser om Grønland, 197, 1-53, 1973.

Deardorff, J. W.: A parameterization of moisture content for use in atmospheric prediction model, J. Appl. Meteorol., 16, 11821185, 1977.

Deser, C., Capotondi, A., Saravanan, R., and Phillips, A.: Tropical Pacific and Atlantic Climate Variability in CCSM3, J. Climate, 19, 2451-2481, doi:10.1175/JCLI3759.1, 2005.

Dickinson, R. E., Oleson, K. W., Bonan, G., Hoffman, F., Thornton, P., Vertenstein, M., Yang, Z.-L., and Zeng, X.: The Community Land Model and its climate statistics as a component of the Community Climate System Model, J. Climate, 19, 2302-2324, 2006

Duplessy, J. C., Labeyrie, L. D., and Waelbroeck, C.: Constraints on the ocean oxygen isotopic enrichment between the last glacial maximum and the Holocene: paleoceanographic implications, Quaternary Sci. Rev., 21, 315-330, 
doi:10.1016/S0277-3791(01)00107-X, 2002.

EPICA-community-members: Eight glacial cycles from an Antarctic ice core, Nature, 429, 623-862, 2004.

Fairbanks, R. G.: A 17,000-year glacio-eustatic sea level record: influence of glacial melting rates on the Younger Dryas event and deep-ocean circulation, Nature, 342, 637-642, 1989.

Feng, X., Faiia, A. M., and Posmentier, E. S.: Seasonality of isotopes in precipitation: a global perspective, J. Geophys. Res., 114, D08116, doi:10.1029/2008JD011279, 2009.

Gat, J. R.: Oxygen and hydrogen isotopes in the hydrologic cycle, Annu. Rev. Earth Planet. Sci., 24, 225-262, 1996.

Hack, J. J., Caron, J. M., Yeager, S. G., Oleson, K. W., Holland, M. M., Truesdale, J. E., and Rasch, P. J.: Simulation of the Global Hydrological Cycle in the CCSM Community Atmosphere Model Version 3 (CAM3): Mean Features, J. Climate, 19, 2199-2221, 2006.

Hansen, J., Lacis, A., Rind, D., Russell, G., Stone, P., Fung, I., Ruedy, R., and Lerner, J.: Climate sensitivity: analysis of feedback mechanisms, In: Climate processes and climate sensitivity, edited by: Hansen, J. and Takahashi, T., Geophys. Mono., 29, Am. Geophys. Union., Washington, DC, 130-163, 1984.

Hewitt, C. D. and Mitchell, J. F. B.: Radiative forcing and response of a GCM to ice age boundary conditions: cloud feedback and climate sensitivity, Clim Dynam., 13, 821-834, 1997.

Hoffmann, G., Werner, M., and Heimann, M.: Water isotope module of the ECHAM atmospheric general circulation model: A study on timescales from days to several years, J. Geophys. Res., 103, 16871-16896, 1998.

IAEA/WMO.: Global Network of Isotopes in Precipitation: The GNIP database, available at: http://www-naweb.iaea.org/napc/ ih/IHS_resources_gnip.html (last access; 10 March 2012), 2006.

Johnsen, S. J., Dansgaard, W., and White, J. W. C.: The origin of Arctic precipitation under present and glacial conditions, Tellus, 41B, 452-468, 1989.

Johnsen, S., Dahl-Jensen, D., Gundestrup, N., Steffensen, J. P., Clausen, H. B., Miller, H., Masson-Delmotte, V., Sveinbjörnsdottir, A. E., and White, J.: Oxygen isotope and palaeotemperature records from six Greenland ice-core stations: Camp Century, Dye-3, GRIP, GISP2, Renland and NorthGRIP, J. Quaternary Sci., 16, 299-308, 2001.

Jouzel, J.: Water Stable Isotopes: Atmospheric composition and applications in polar ice core studies, in: Treatise on Geochemistry, Elsevier Ltd., ISBN: 978-0-08-043751-4, 2003.

Jouzel, J., Koster, R. D., Suozzo, R. J., Russel, G. L., White, J. W. C., and Broecker, W. S.: Simulations of the HDO and $\mathrm{H}_{2} \mathrm{O}^{18}$ atmospheric cycles using the NASA GISS General Circulation Model: The seasonal cycle for present-day conditions, J. Geophys. Res., 92, 14739-14760, 1987.

Jouzel, J., Koster, R. D., Suozzo, R. J., and Russell, G. L.: Stable water isotope behavior during the last glacial maximum: a general circulation model analysis, J. Geophys. Res., 99, 2579125801, 1994.

Jouzel, J., Alley, R. B., Cuffey, K. M., Dansgaard, W., Grootes, P., Hoffmann, G., Johnsen, S. J., Koster, R. D., Shuman, C. A., Stievenard, M., Stuiver, M., and White, J. W. C.: Validity of the temperature reconstruction from water isotopes in ice cores, J. Geophys. Res., 102, 26471-26487, 1997.

Kageyama, M. and Valdes, P.: Impact of the North American ice sheet orography on the Last Glacial Maximum eddies and snow- fall, Geophys. Res. Lett., 27, 1515-1518, 2000.

Kim, S. J.: The effect of atmospheric $\mathrm{CO}_{2}$ and ice sheet topography on LGM climate, Clim. Dynam., 22, 639-651, doi:10.1007/s00382-004-0412-2, 2004.

Kutzbach, J. E. and Guetter, P. J.: The Influence of Changing Orbital Parameters and Surface Boundary Conditions on Climate Simulations for the Past 18,000 Years, J. Atmos. Sci., 43, 1726-1759, 1986.

Lambeck, K. and Chappell, J.: Sea level change through the last glacial cycle, Science, 292, 679-686, 2001.

Lautenschlager, M. and Santer, B. D.: Atmospheric Response to a Hypothetical Tibetan Ice Sheet, J. Climate, 4, 386-394, 1991.

Lee, J. E., Fung, I., DePaolo, D. J., and Henning, C. C.: Analysis of the global distribution of water isotopes using the NCAR atmospheric general circulation model, J. Geophys. Res., 112, D16306, doi:10.1029/2006JD007657, 2007.

Lee, J. E., Fung, I., DePaolo, D. J., and Otto-Bliesner, B. L.: Water isotopes during the Last Glacial Maximum: New GCM calculations, J. Geophys. Res., 113, D19109, doi:10.1029/2008JD009859, 2008.

Levis, S., Bonan, G. B., and Bonfils, C.: Soil feedback drives the mid-Holocene North African monsoon northward in fully coupled CCSM2 simulations with a dynamic vegetation model, Clim. Dynam., 23, 791-802, 2004.

Liu, Z., Carlson, A. E., He, F., Brady, E. C., Otto-Bliesner, B. L., Briegleb, B., Wehrenberg, M., Clark, P. U., Wu, S., Cheng, J., Zhang, J. X., Noone, D., and Zhu, J.: Younger Dryas Cooling and the Greenland Climate Response to $\mathrm{CO}_{2}$, Proc. Natl. Acad. Sci., 109, 11101-11104, doi:10.1073/pnas.1202183109, 11101.11104., 2012.

Lorius, C., Jouzel, J., Ritz, C., Merlivat, L., Barkov, N. I., Korotkevich, Y. S., and Kotlyakov, V. M.: A 150,000-year climatic record from Antarctic ice, Nature, 316, 591-596, 1985.

Mahfouf, J.-F., Cariolle, D., Royer, J.-F., Geleyn, J.-F., and Timbal, B.: Response of the METEO-FRANCE climate model to changes in $\mathrm{CO}_{2}$ and sea-surface-temperature, Clim. Dynam., 9, 345-362, 1994.

Manabe, S.: Climate and the ocean circulation: 1. The atmospheric circulation and the hydrology of the earth's surface, Mon. Weather Rev., 97, 739-805, 1969.

Manabe, S. and Broccoli, A. J.: The influence of continental ice sheets on the climate of an ice age, J. Geophys. Res., 90, 21672190, 1985.

Masson-Delmotte, V., Kageyama, M., Braconnot, P., Charbit, S., Krinner, G., Ritz, C., Guilyardi, E., Jouzel, J., Abe-Ouchi, A., Crucifix, M., Gladstone, R. M., Hewitt, C. D., Kitoh, A., Legrande, A., Marti, O., Merkel, U., Motoi, T., Ohgaito, R., OttoBliesner, B., Peltier, W. R., Ross, I., Valdes, P. J., Vettoretti, G., Weber, S. L., and Wolk, F.: Past and future polar amplification of climate change: climate model intercomparisons and ice-core constraints, Clim. Dynam., 26, 513-529, 2006.

Masson-Delmotte, V., Hou, S., Ekaykin, A., Jouzel, J., Aristarain, A., Bernardo, R. T., Bromwhich, D., Cattani, O., Delmotte, M., Falourd, S., Frezzotti, M., Gallée, H., Genoni, L., Isaksson, E., Landais, A., Helsen, M., Hoffmann, G., Lopez, J., Morgan, V., Motoyama, H., Noone, D., Oerter, H., Petit, J. R., Royer, A., Uemura, R., Schmidt, G. A., Schlosser, E., Simões, J. C., Steig, E., Stenni, B., Stievenard, M., van den Broeke, M., Van de Wal, R., Van den Berg, W.-J., Vimeux, F., and White, J. W. C.: A review 
of Antarctic surface snow isotopic composition: observations, atmospheric circulation and isotopic modelling, J. Climate, 21, 3359-3387, 2008.

Masson-Delmotte, V., Buiron, D., Ekaykin, A., Frezzotti, M., Gallée, H., Jouzel, J., Krinner, G., Landais, A., Motoyama, H., Oerter, H., Pol, K., Pollard, D., Ritz, C., Schlosser, E., Sime, L. C., Sodemann, H., Stenni, B., Uemura, R., and Vimeux, F.: A comparison of the present and last interglacial periods in six Antarctic ice cores, Clim. Past, 7, 397-423, doi:10.5194/cp-7397-2011, 2011.

MARGO Project Members (Waelbroeck, C., Paul, A., Kucera, M., Rosell-Melé, A., Weinelt, M., Schneider, R., Mix, A. C., Abelmann, A., Armand, L., Bard, E., Barker, S., Barrows, T.T., Benway, H., Cacho, I., Chen, M. T., Cortijo, E., Crosta, X., de Vernal, A., Dokken, T., Duprat, J., Eldereld, H., Eynaud, F., Gersonde, R., Hayes, A., Henry, M., Hillaire-Marcel, C., Huang, C. C., Jansen, E., Juggins, S., Kallel, N., Kiefer, T., Kienast, M., Labeyrie, L., Leclaire, H., Londeix, L., Mangin, S., Matthiessen, J., Marret, F., Meland, M., Morey, A. E., Mulitza, S., Pflaumann, U., Pisias, N. G., Radi, T., Rochon, A., Rohling, E. J., Sbaf, L., Schäfer-Neth, C., Solignac, S., Spero, H., Tachikawa, K., and Turon, J. L.): Constraints on the magnitude and patterns of ocean cooling at the Last Glacial Maximum, Nat. Geosci., 2, 127-332, 2009.

Merkel, U., Prange, M., and Schulz, M.: ENSO variability and teleconnections during glacial climate, Quaternary Sci. Rev., 29, 86100, 2010

Meehl, G. A., Arblaster, J. M., Lawrence, D. M., Seth, A., Schneider, E. K., Kirtman, B. P., and Min, D.: Monsoon regimes in the CCSM3, J. Climate, 19, 2482-2495, doi:10.1175/JCLI3745.1, 2006.

Noone, D.: Water isotopes in CCSM for studying water cycles in the climate system, 8th Annual CCSM workshop, Breckenridge, Colorado, 2003.

Noone, D.: Isotopic composition of water vapor modeled by constraining global climate simulations with reanalyses, Research Activities in Atmospheric and Oceanic Modeling, edited by: Cote, J., Report No. 35, World Meteorological Organization, 237, 2006.

Noone, D. and Simmonds, I.: Associations between $\delta^{18} \mathrm{O}$ of water and climate parameters in a simulation of atmospheric circulation for 1979-95, J. Climate, 15, 3150-3169, 2002.

Noone, D. and Sturm, C.: Comprehensive dynamical models of global and regional water isotope distributions, in: Isoscapes: Understanding movement, pattern, and process on Earth through isotope mapping, Springer Verlag, 2009.

Otto-Bliesner, B. L., Brady, E. C., Clauzet, G., Tomas, R., Levis, S., and Kothavala, Z.: Last glacial maximum and Holocene climate in CCSM3, J. Climate, 19, 2526-2544, 2006a.

Otto-Bliesner, B. L., Tomas, R., Brady, E. C., Ammann, C., Kothavala, Z., and Clauzet, G.: Climate sensitivity of moderateand low-resolution versions of CCSM3 to pre-industrial forcings, J. Climate, 19, 2567-2583, 2006b.

Otto-Bliesner, B. L., Schneider, R., Brady, E. C., Kucera, M., AbeOuchi, A., Bard, E., Braconnot, P., Crucifix, M., Hewitt, C. D., Kageyama, M., Marti, O., Paul, A., Rosell-Mele, A., Waelbroeck, C., Weber, S. L., Weinelt, M., and Yu, Y.: A comparison of PMIP2 model simulations and the MARGO proxy reconstruction for tropical sea surface temperatures at last glacial max- imum, Clim. Dynam., 32, 799-815, doi:10.1007/s00382-0080509-0, 2009.

Pausata, F. S. R., Li, C., Wettstein, J. J., Kageyama, M., and Nisancioglu, K. H.: The key role of topography in altering North Atlantic atmospheric circulation during the last glacial period, Clim. Past, 7, 1089-1101, doi:10.5194/cp-7-1089-2011, $2011 \mathrm{a}$.

Pausata, F. S. R., Battisti, D. S., Nisancioglu, K. H., and Bitz, C. M.: Chinese stalagmite $\delta^{18} \mathrm{O}$ controlled by changes in the Indian monsoon during a simulated Heinrich event, Nat. Geosci., 4, 474-480, 2011b.

Peltier, W. R.: Global glacial isostasy and the surface of the ice-age Earth: the ICE-5G (VM2) model and GRACE, Annu. Rev. Earth Planet. Sci., 32, 111-149, 2004.

Petit, J. R., Jouzel, J., Raynaud, D., Barkov, N. I., Barnola, J.-M., Basile, I., Bender, M., Chappellaz, J., Davis, M., Delaygue, G., Delmotte, M., Kotlyakov, V. M., Legrand, M., Lipenkov, V. Y., Lorius, C., Pe'pin, L., Ritz, C., Saltzman, E. and Stievenard.: Climate and atmospheric history of the past 420,000 years from the Vostok ice core, Antarctica, Nature, 399, 429-436, 1999.

Rasch, P. J. and Williamson, D. L.: On shape-preserving interpolation and semi-Lagrangian transport, SIAM J. Sci. Stat. Comput., 11, 656-687, 1990.

Rind, D.: Components of the ice age circulation, J. Geophys. Res., 92, 4241-4281, 1987.

Risi, C., Bony, S., Vimeux, F., and Jouzel, J.: Water-stable isotopes in the LMDZ4 general circulation model: Model evaluation for present-day and past climates and applications to climatic interpretations of tropical isotopic records, J. Geophys. Res., 115, D12118, doi:10.1029/2009JD013255, 2010.

Rozanski, K. and Araguas-Araguas, L.: Spatial and temporal variability of stable isotope composition of precipitation over the South American Continent, Bull. Inst. Fr. Etudes Andines., 24 379-390, 1995.

Rozanski, K., Araguas-Araguas, L., and Gonfiantini, R.: Isotopic patterns in modern global precipitation, in: Climate Change in Continental Isotopic Records, 1-36, Geophys. Monograph, 78, 1-36, doi:10.1029/GM078p0001, 1993.

Schmidt, G. A., LeGrande, A. N., and Hoffmann, G.: Water isotope expressions of intrinsic and forced variability in a coupled ocean-atmosphere model, J. Geophys. Res., 112, D10103, doi:10.1029/2006JD007781, 2007.

Severinghaus, J. P. and Brook, E. J.: Abrupt climate change at the end of the last glacial period inferred from trapped air in polar ice, Science, 286, 930-934, 1999.

Severinghaus, J. P., Sowers, T., Brook, E. J., Alley, R. B., and Bender, M. L.: Timing of abrupt climate change at the end of the Younger Dryas interval from thermally fractionated gases in polar ice, Nature, 391, 141-146, doi:10.1038/34346, 1998.

Shin, S. I., Liu, Z., Otto-Bliesner, B. L., Brady, E. C., Kutzbach, J. E., and Harrison, S. P.: A simulation of the Last Glacial Maximum Climate using the NCAR CCSM, Clim. Dynam., 20, 127151, 2002.

Sime, L. C., Tindall, J. C., Wolff, E. W., Connolley, W., and Valdes, P. J.: Antarctic isotopic thermometer during a $\mathrm{CO}_{2}$ forced warming, J. Geophys. Res., 113, D24119, doi:10.1029/2008JD010395, 2008.

Staniforth, A. and Côté, J.: Semi-Lagrangian integration schemes for atmospheric Models - A review, Mon. Weather Rev., 119, 2206-2223, 1991. 
Stein, U. and Alpert, P.: Factor separation in numerical simulations, J. Atm. Sci., 50, 2107-2115, 1993.

Stenni, B., Jouzel, J., Masson-Delmotte, V., Castellanoc, E., Cattani, O., Falourd, S., Johnsen, S. J., Longinelli, A., Rothlisberger, R., Sachs, J. P., Selmo, E., Souchez, R., Steffensen, J. P., and Udisti, R.: A late-glacial high-resolution site and source temperature record derived from the EPICA Dome C isotope records (East Antarctica), Earth Planet. Sci. Lett., 217, 183-195, 2004.

Sturm, C., Zhang, Q., and Noone, D.: An introduction to stable water isotopes in climate models: benefits of forward proxy modelling for paleoclimatology, Clim. Past, 6, 115-129, doi:10.5194/cp-6-115-2010, 2010.

Sylvestre, F.: Moisture Pattern During the Last Glacial Maximum in South America, in: Past Climate Variability in South America and Surrounding Regions, Springer Netherlands, 2009.

Thompson, L. G., Mosley-Thompson, E., and Henderson, K. A.: Ice-core palaeoclimate records in tropical South America since the Last Glacial Maximum, J. Quaternary Sci., 15, 377-394, 2000.

Timbal, B., Mahfouf, J. F., Royer, J. F., Cubasch, U., and Murphy, J. M.: Comparison between double $\mathrm{CO}_{2}$ time slice and coupled experiments, J. Climate, 10, 1463-1469, 1997.
Tindall, J. C., Valdes, P., and Sime, L. C.: Stable water isotopes in HadCM3: Isotopic signature of El Niño-Southern Oscillation and the tropical amount effect, J. Geophys. Res., 114, D04111, doi:10.1029/2008JD010825, 2009.

Van Campo, E.: Monsoon fluctuations in two 20,000-Yr B.P. Oxygen-isotope/pollen records off south-west India, Quaternary Res., 26, 376-388, 1986.

Werner, M., Mikolajewicz, U., Heimann, M., and Hoffmann, G.: Borehole versus isotope temperatures on Greenland: Seasonality does matter, Geophys. Res. Lett., 27, 723-726, 2000.

Werner, M., Heimann, M., and Hoffmann, G.: Isotopic composition and origin of polar precipitation in present and glacial climate simulations, Tellus, 53B, 53-71, 2001.

Williamson, D. L. and Olson, J. G.: Climate simulations with a Semi-Lagrangian version of the NCAR community climate model, Mon. Weather Rev., 122, 1594-1610, 1994.

Williamson, D. L. and Rasch, P. J.: Two-dimensional semiLagrangian transport with shape preserving interpolation, Mon. Weather Rev., 117, 102-129, 1989.

Williamson, D. L. and Rasch, P. J.: Water vapor transport in the NCAR CCM2, Tellus, 46A, 34-51, 1993. 